Harmful Algae

January 2016, Volume 51 Pages 26-39

http://dx.doi.org/10.1016/i.hal.2015.10.017

http://archimer.ifremer.fr/doc/00299/40983/

(c) 2015 Elsevier B.V. All rights reserved.

\title{
Two decades of Pseudo-nitzschia spp. blooms and king scallop (Pecten maximus) contamination by domoic acid along the French Atlantic and English Channel coasts: Seasonal dynamics, spatial heterogeneity and interannual variability
}

\author{
Husson Berengere ${ }^{1}$, Hernández-Fariñas Tania ${ }^{2,3}$, Le Gendre Romain ${ }^{4}$, Schapira Mathilde ${ }^{5}$, \\ Chapelle Annie ${ }^{6,{ }^{*}}$
}

1 IFREMER, REM-EEP-LEP, BP 70, 29280 Plouzané, France

2 Station Biologique de Roscoff (Roscoff Marine Station)- Place Georges Teissier, 29680 Roscoff, France

${ }^{3}$ Centre Ifremer de Brest - Pointe du Diable, 29280 Plouzané, France

${ }^{4}$ IFREMER, Unité de Recherche Lagons, Ecosystèmes et Aquaculture Durable (LEAD-NC), BP 2059, Nouméa 98846, New Caledonia, France

${ }^{5}$ IFREMER, LER/N, Avenue du Général de Gaulle, 14520 Port en Bessin, France

${ }^{6}$ IFREMER, Dyneco/PELAGOS, BP 70, 29280 Plouzané, France

* Corresponding author: Annie Chapelle, Tel.: +33 298224356. ;

email address : annie.chapelle@ifremer.fr

\begin{abstract}
:
King scallop contamination (Pecten maximus) by domoic acid, a neurotoxin produced by some species of the diatom Pseudo-nitzschia, is highly problematic because of its lengthy retention in the bivalve tissue, leading to prolonged fishery closures. Data collected within the French Phytoplankton and Phycotoxin monitoring network (REPHY) over the 1995-2012 period were used to characterize the seasonal dynamics and the interannual variability of $P$.-nitzschia spp. blooms as well as the contamination of king scallop fishing grounds, in six contrasted bays distributed along the French Atlantic coast and English Channel. Monitoring revealed that these toxic events have become more frequent since the year 2000, but with varying magnitudes, frequencies and timing depending on the bay. Two bays, located in southern Brittany, exhibited both recurrent contaminations and high $P$.nitzschia abundances. The Brest bay and the Seine bay were intermittently affected. The Pertuis Breton exhibited only one major toxic event related to an exceptionally intense bloom of P.-nitzschia in 2010, and the Saint Brieuc bay neither showed significant contamination nor high P.-nitzschia abundance. While high $P$.-nitzschia abundance appeared to be correlated to scallop toxicity, this study highlights the difficulty in linking P.-nitzschia spp. blooms to king scallop contamination through monitoring. Indeed, $P$.-nitzschia was determined at the genus level and data regarding species abundances and their toxicity levels are an absolute prerequisite to further assess the environmental control of ASP events. As results describe distinct $P$.-nitzschia bloom dynamics along the French coast, this may suggest distinct controlling factors. They also revealed that major climatic events, such as the winter storm
\end{abstract}


Xynthia in 2010, can trigger toxicity in P.-nitzschia over a large spatial scale and impact king scallop fisheries all along the coast.

\section{Highlights}

- Pseudo-nitzschia blooms occur from May to September along the English Channel/Atlantic French coast. Irradiance and temperature play a major role on Pseudo-nitzschia blooms initiation in spring. - Intense Pseudo-nitzschia spp. blooms is a prerequisite for king scallop contamination by domoic acid. ASP events tend to be more frequent in bays strongly influenced by riverine inputs and/or transitional upwelling. Large-scale climatic events could stimulate toxic Pseudo-nitzschia blooms and toxicity.

Keywords: Pseudo-nitzschia spp., Domoic acid, King scallop, Interannual variability, Seasonal dynamics, Environmental parameters 


\section{Introduction}

The pennate diatom Pseudo-nitzschia (Heterokonta, Bacillariophyceae) is a cosmopolitan genus that has been linked to many toxic events worldwide (e.g. Trainer et al., 2012). To date, a dozen species of this genus have been identified as being able to produce domoic acid (DA) (e.g. Bates and Trainer, 2006; Lelong et al., 2012), a potent neurotoxin responsible for Amnesic Shellfish Poisoning (ASP) syndrome in humans after the consumption of contaminated filter feeders (Bates et al., 1998; Wright et al., 1989). Symptoms of this poisoning are more or less severe gastrointestinal and neurological disorders and may even lead to death in the most extreme cases (Jeffery et al., 2004). Toxic Pseudo-nitzschia (PSN) outbreaks are also responsible for massive mortalities in marine wildlife, such as marine mammals and sea birds, through the trophic transfer of the toxin (e.g. Scholin et al., 2000; Lefebvre et al., 2002a,b; Shumway et al., 2003; Bargu et al., 2012; Lefebvre et al., 2012). Toxic PSN blooms therefore represent an expanding risk for both human health and activities such as fisheries and aquaculture, as well as for marine wildlife worldwide (Hallegraeff, 1993; Glibert et al., 2005).

Over the last decade, ASP events have strongly impacted fisheries in European waters (EFSA, 2009). Toxic PSN blooms have resulted in prolonged closure of king scallop (Pecten maximus) harvesting in Ireland (Bogan et al., 2007a,b), Scotland (Campbell et al., 2001; Gallacher et al., 2001), Portugal (Vale and Sampayo, 2001), Spain (Arévalo et al., 1998; Fragaet al., 1998) and France (Nézan et al., 2006). King scallop contamination by DA is highly problematic because of its lengthy retention in the bivalve tissue, which in extreme cases can last more than one year (e.g. Doucette et al., 2006; Blanco et al., 2002). In France, Pecten maximus fishing grounds are distributed along the French Atlantic and English Channel coasts, with a production ranging between 15000 and 20000 tons per year. Since the first detection of DA in mussel tissues in 1998 (i.e. $0.5 \mu \mathrm{g} \mathrm{g}^{-1}$ of wet weight, hereafter ww; 
Amzil et al., 2001), DA levels are systematically monitored in king scallop tissues before and during harvesting periods, within the framework of the French Phytoplankton and Phycotoxin monitoring network (REPHY). In addition, phytoplankton community composition is monitored at a fortnightly or monthly frequency. When PSN densities exceed the alert threshold of $100000 \mathrm{c}$ ellsl ${ }^{-1}$, DA analysis are systematically carried out in king scallop tissues. Since 2004, several ASP events, characterized by DA concentrations well above the European Union regulatory limit (i.e. $>20 \mu \mathrm{gg}^{-1} \mathrm{ww}$ ), have been observed along the French coast, leading to extended closures of many harvesting sites and causing serious economic losses for the French fleet (Belin et al., 2013).

Given its potential impact on local economies and human health, a better knowledge of the spatial and temporal dynamics of PSN blooms and ASP events affecting French scallop fisheries is an absolute prerequisite to further assessing the determinism of the PSN toxic blooms, and ultimately to developing predictive models of toxigenic PSN blooms. Despite the large available dataset from the REPHY monitoring network, seasonal dynamics and interannual variability of PSN blooms have not yet been described. This study represents the first step towards an improved understanding of toxic Pseudo-nitzschia bloom dynamics and ASP events along the French coast.

In this context, the objectives of this study were to (i) describe the seasonal dynamics of Pseudo-nitzschia spp. blooms in six contrasted bays scattered along the coast, (ii) to estimate scallop contamination by domoic acid over an interannual time scale and investigate a possible link with the intensity of PSN blooms and (iii) to finally discuss the potential role of environmental factors influencing toxic PSN outbreaks along the coast.

\section{Materials and Methods}

\subsection{Study sites}


This study was conducted in six bays scattered along the French Atlantic and English Channel coasts (Fig. 1). Among the different sampling stations monitored within the REPHY, one station was selected in each bay (Table 1). The choice of these stations was conditioned by (i) the time range and frequency of the available data sets, (ii) the presence of exploited scallop fishing grounds, (iii) the recurring observation of PSN within the phytoplankton community and (iv) the representativeness of hydrological features encountered in the bay. The data collected at these selected sampling stations was used throughout the manuscript. For the sake of clarity, the term 'bay' will be used thereafter.

Despite these common features, the study sites exhibit very different hydro-climatic and biological characteristics (Fig. 1, 2 and Table 2).

- The Seine Bay covers $4000 \mathrm{~km}^{2}$ with a mean depth around $15 \mathrm{~m}$ and is characterized by a megatidal regime, with a tidal range reaching more than $7 \mathrm{~m}$ (Guillaud et al., 2000). The bay receives large freshwater inputs mainly from the Seine River (interannual mean flow $=510$ $\left.\mathrm{m}^{3} \mathrm{~s}^{-1}\right)$. The Seine bay exhibits the highest phytoplankton biomass out of the six study sites, with median interannual Chlorophyll $a(\mathrm{Chl} a)$ reaching $4.1 \mu \mathrm{g} \mathrm{1^{-1 }}$ at the chosen sampling station (Table 2). High Chlorophyll $a$ levels are regularly observed in the Seine river plume during the productive seasons, with mean values reaching $20 \mu \mathrm{g}^{-1}$ and extreme values peaking at $60 \mu \mathrm{g} \mathrm{l}^{-1}$ (Cugier et al., 2005). Important freshwater inputs cause high winter nutrient concentrations with median values of $1 \mu \mathrm{mol} \mathrm{l}^{-1}, 23 \mu \mathrm{mol} \mathrm{l}^{-1}$ and $43 \mu \mathrm{mol} \mathrm{l}^{-1}$ for $\mathrm{PO}_{4}$ $(\mathrm{P}), \mathrm{SiOH}(\mathrm{Si})$ and dissolved inorganic nitrogen $(\mathrm{N})$ respectively, with N/P always above the Redfield ratio (median of 44.1), highlighting important nitrogen enrichment (Fig. 2). King scallop harvesting in the Seine bay represents $50 \%$ to $70 \%$ of national production (i.e. 5000 to 15000 t year $\left.^{-1}\right)$.

- The Saint Brieuc bay is widely open to the Western English Channel. It has a clockwise circulation pattern,with water masses accelerating in the western part of the bay (Garreau, 
1993). This bay is weakly influenced by freshwater inputs and median interannual Chl $a$ reaches $0.7 \mu \mathrm{g} 1^{-1}$. This bay displays the lowest phytoplankton biomass recorded out of the six study sites (Fig. 1 and Table 2). Lowest $\mathrm{N}$ and Si concentrations are recorded in the Saint Brieuc Bay, where maximum winter concentrations remain below $20 \mu \mathrm{mol} 1^{-1}$ and $12 \mu \mathrm{mol} 1^{-1}$ respectively (Fig. 2). N/P ratio is also the lowest observed (23), close to the Redfield ratio. The king scallop fishery is one of the major activities of the bay with a landing of 5000 to 10 000 t year $^{-1}$.

- The Brest Bay is a semi-enclosed bay of $180 \mathrm{~km}^{2}$ connected to the Iroise Sea by a narrow (2 $\mathrm{km}$ wide) and deep (40 m) strait. The bay is characterized by strong currents (Le Pape and Ménesguen, 1997) and receives relatively high freshwater inputs mainly from the Aulne and Elorn rivers (total interannual mean flow $=35 \mathrm{~m}^{3} \mathrm{~s}^{-1}$ ). Annual median Chl $a$ reaches $1.0 \mu \mathrm{g} 1^{-1}$. The bay displays high nitrogen enrichment during winter (median N/P of 49) and relatively high $\mathrm{P}$ and Si concentrations (median of 0.58 and $12 \mu \mathrm{mol} \mathrm{l}^{-1}$ respectively). Around 200 tons of king scallops are harvested every year in the bay.

- Concarneau and Quiberon bays, located in the northern Bay of Biscay are characterized by weak tidal currents and receive indirect freshwater inputs, as the Loire and Vilaine river plumes tend to spread towards the NW (Fig. 1) and remain confined along the coast particularly in early spring (Lazure and Jegou, 1998). These freshwater inputs combined with low vertical mixing cause strong haline stratification within the bay (Planque et al., 2004). From spring to mid-September, thermal stratification is superimposed onto haline stratification. In spring low-surface salinity waters induce a significant density gradient over the continental shelf generally oriented northwards $\left(2-20 \mathrm{~cm} \mathrm{~s}^{-1}\right)$. During thermal stratification, W/NW winds induce local transitory upwelling (Lazure and Jégou 1998; Puillat et al., 2004, 2006). In the Concarneau and Quiberon bays annual median Chl $a$ reaches $1.1 \mu \mathrm{g}$ $1^{1}$ and $1.3 \mu \mathrm{g}^{-1}$ respectively (Fig. 1 and Table 2). The two bays differ in their winter nutrient 
151

152

153

154

155

156

157

158

159

160

161

162

163

164

165

166

167

168

169

170

171

172

173

174

175

supply, with high median values of $\mathrm{P}, \mathrm{Si}$ and $\mathrm{N}$ concentrations $\left(0.63,20\right.$ a nd $25 \mu \mathrm{mol} \mathrm{l^{- }}$ ${ }^{1}$ respectively) and high median N/P ratio (41) for Quiberon, versus low median concentrations $\left(\mathrm{P}=0.42, \mathrm{Si}=9, \mathrm{~N}=11 \mu \mathrm{mol} \mathrm{1^{-1 }}\right)$ and lower median N/P (26) for Concarneau. Around 3000 tons of king scallops are harvested each year in these two bays.

- The Pertuis Breton located in the Southern Bay of Biscay is a shallow bay (i.e. $<20 \mathrm{~m}$ depth) characterized by a macrotidal regime, weak currents (i.e. $<2$ knots) and high turbidity (annual median value of 9.1 NTU; Table 2). Only small rivers flow into the bay: the Lay river $\left(20 \mathrm{~m}^{3} \mathrm{~s}^{-}\right.$ $\left.{ }^{1}\right)$ and the Seudre-Niortaise river $\left(25 \mathrm{~m}^{3} \mathrm{~s}^{-1}\right)$. Phytoplankton biomass is relatively high, with annual median Chla concentrations of $2.8 \mu \mathrm{g} 1^{-1}$. The bay experiences high nutrient discharge during the winter with median $\mathrm{P}, \mathrm{Si}$ and $\mathrm{N}$ concentrations of $0.66,18$ and $30 \mu \mathrm{mol} \mathrm{l}^{-1}$, and an N/P median ratio of 53. Only 600 to 700 tons of king scallops are landed each year in this area.

\subsection{Data collection and sample analysis}

Since 1987, the REPHY program has been acquiring information on ph ytoplankton communities along the French coast. Sampling is carried out (i) on a monthly basis from November to March (ii) every two months from April to October and (iii) weekly when potentially toxic species abundances go over specific thresholds. Water samples are collected from sub-surface $(1 \mathrm{~m})$ waters using a 5-1 Niskin bottle, 1 nautical mile offshore and are timed to coincide with high tide.

\subsubsection{Phytoplankton analysis}

Phytoplankton biomass was estimated through chlorophyll $a$ concentrations and phytoplankton abundances and diversity were assessed through microscopy numeration 
within the REPHY program.

Samples were collected following three strategies (Belin and Amzil, 2010): (i) FLORTOT, a sampling strategy where all micro-phytoplankton (i.e. $>20 \mu \mathrm{m}$, and colonies) present in the sample are counted; (ii) FLORIND, which only counts toxic species of phytoplankton exceeding 100000 cells $1^{-1}$; (iii) FLORPAR, which is activated for exceptional blooms or toxic events and induces an increase in the sampling frequency.

For chlorophyll $a$ concentrations, water samples $(200$ to $2000 \mathrm{ml})$ were filtered through glass-fiber filters (Whatman $\mathrm{GF} / \mathrm{F})$ and immediately frozen $\left(-20^{\circ} \mathrm{C}\right)$ until analysis. Chlorophylleous pigments were subsequently extracted in $5 \mathrm{ml}$ of $90 \%$ acetone in the dark at $4^{\circ} \mathrm{C}$ during 12 hours and assayed in a spectrophotometer following Lorenzen (1967).

For phytoplankton identification, 1-1 water samples were fixed with Lugol iodine solution ( $2 \%$ f.c.) and stored in the dark at $4{ }^{\circ} \mathrm{C}$. In the laboratory, samples were gently homogenized before settling in 10-ml sub-samples for $>24 \mathrm{~h}$ in Hydro-Bios counting chambers (Utermöhl, 1958).

Phytoplankton identification was performed using an inverted microscope equipped with phase contrast illumination. In order to guarantee the taxonomic homogeneity of data over time and among sampling sites, some species and some genera were aggregated into taxonomic units (TU) corresponding to the lowest taxonomic level possible. This grouping was chosen in order to overcome difficulties of identification between some species or genera using optical microscopy.

While PSN has been monitored since 1995 within the REPHY monitoring network, species level identification by light microscopy is difficult or even impossible for some species and therefore most of the data refer to the genus scale. Consequently, analyses were carried out using time series of Pseudo-nitzschia spp. abundances. 


\subsubsection{Environmental parameters}

At each sampling station, salinity, water temperature $\left({ }^{\circ} \mathrm{C}\right)$ and turbidity (NTU) were recorded in subsurface waters $(1 \mathrm{~m})$ with YSI $6600 \mathrm{M}$ multiparameter probes (Fondriest).

Since 2007, nutrient concentrations have been estimated on a monthly basis over the winter period (i.e. October to March) in each of the six bays within the framework of the European Water Framework Directive. In the Seine, Quiberon and Concarneau bays, monthly sampling has been carried out throughout the year since 2002, 1995 and 1997 respectively.

For inorganic nutrients, $100-\mathrm{ml}$ water samples were pre-filtered through $48 \mu \mathrm{m}$ mesh directly from the Niskin bottle. For silicate concentrations $\left(\mathrm{Si}=\left[\mathrm{Si}(\mathrm{OH})_{4}\right]\right)$, water samples were subsequently filtered through $0.45 \mu \mathrm{m}$ acetate cellulose membrane and stored at $4^{\circ} \mathrm{C}$ before analysis. Water samples for the determination of dissolved inorganic nitrogen (i.e. $\left.\mathrm{N}=\left[\mathrm{NO}_{3}^{-}+\mathrm{NO}_{2}^{-}\right]+\left[\mathrm{NH}_{4}^{+}\right]\right)$and phosphate concentrations $\left(\mathrm{P}=\left[\mathrm{PO}_{4}^{3-}\right]\right)$ arewere stored directly at $-20^{\circ} \mathrm{C}$. Samples wereanalyzed within one month after field collection with an auto-analyzer (Technicon III) following standard protocols (Kérouel and Aminot, 1997; Hydes et al., 2010). Photosynthetic Active Radiations (PAR) data were obtained with the ARPEGE model (Météo France) and the daily PAR was summed over the five days preceding sampling.

\subsubsection{Domoic acid in king scallops}

Routine monitoring of domoic acid (DA) concentration in king scallops has been performed within the REPHY program since 2003 in exploited fishing grounds scattered along the French coast. King scallops are collected fortnightly just before and during the harvesting period (i.e. November to March) as long as the DA concentration remains below the sanitary threshold (i.e. $20 \mu \mathrm{g} \mathrm{DA} \mathrm{g} \mathrm{g}^{-1} \mathrm{ww}$ ). When toxin levels exceed the sanitary threshold, samples are then collected weekly on the impacted fishing grounds. Scallop tissue 
samples (i.e. total shellfish meat) are analyzed for DA concentration using a UV diode array, following standard protocols (Lawrence et al., 1991). Only DA concentrations in the total shellfish flesh have been retained in the data analysis.

As sampling frequency was not homogenous within and among sampling sites and considering the long retention time of DA in king scallop tissues (sometimes over a year), DA concentrations measured at a particular time may be the result of different contamination periods, and may therefore be linked to different toxic PSN blooms. In order to overcome this difficulty, an annual index, (hereafter referred to as the Scallop Toxicity Index (STI), was calculated for each of the six bays over the 2003 to 2012 period. The annual steepest increase in DA concentration was identified in each sampling site. The two dates framing this maximal increase (hereafter referred to as $t_{i}$, date of the beginning of the increase and $t_{f}$, date ending the steep increase) defined the main period of scallop contamination for a given year. The maximum DA level was then identified among four sampling values: the value $\mathrm{at}_{\mathrm{f}}$ and the values of the $3 \mathrm{~s}$ ampling dates following $\mathrm{t}_{\mathrm{f.}}$ This timeframe was chosen for two reasons: $\mathrm{i}$ ) while $t_{f}$ marked the end of the steepest increase of the year, it didn't always correspond to the maximum DA concentrations (i.e. DA concentrations can keep on increasing at a slower rate after $t_{f}$ ) and ii) due to irregular sampling frequencies over time and between sites, this time frame can range from three weeks to several months, which seemed sufficient for the contamination to reach its maximum. Finally, the STI $\left(\mu \mathrm{g} \mathrm{DA} \mathrm{g} \mathrm{g}^{-1} \mathrm{w} \mathrm{y}^{-1}\right)$ was calculated as the difference between the maximum DA concentration and the lowest DA concentration observed over the period preceding $t_{i}$.

\subsection{Data analyses}

A first dataset merging the three strategies (i.e. FLORTOT, FLORIND, and FLORPAR) was used to study the seasonal and interannual dynamics of the genus Pseudo-nitzschia in the 
different bays.

A second database built only with the FLORTOT strategy, was used to calculate biodiversity indices such as (i) total micro-phytoplankton abundance, (ii) phytoplankton richness, (iii) Berger-Parker evenness (Berger and Parker, 1970) and (iv) the ratio between Diatoms and Diatoms plus Dinoflagellates. In addition, a rank was assigned for each taxonomic unit (i.e. TU) based on their relative frequencies in decreasing order; the first ranked TU exhibiting the highest relative frequency (Frontier, 1985; Legendre and Legendre 1998). Only PSN ranks and proportions among the other phytoplankton genus were used in the analysis. In order toTo standardize the data, abundances were averaged over a $14 \mathrm{~d}$ ay period in both datasets.

All analyses were conducted with R software 3.0.0. (R Core Team, 2013). Potential differences and similarities among sampling sites regarding PSN blooms were assessed through a Principal Component Analyses (PCA) performed on the phytoplankton biodiversity indices listed above. PSN bloom descriptors such as PSN absolute, relative abundances and the rank of PSN within the phytoplankton community were calculated using the package FactoMineR (Lê et al. 2008). Missing data were previously imputed thanks to the function impute PCA from the package missMDA (Josse et al., 2012). The factor "site" was used as a qualitative supplementary variable and for each site confidence ellipses were drawn around $95 \%$ of the individuals of each sampling site.

Finally, a niche analysis was performed, using environmental data and PSN abundances. Niche concept relates the environmental conditions with the presence and development of a specific species. In 1957, $\mathrm{H}$ utchinson defined the ecological niche as the space of environmental conditions in which a species is able to persist. Furthermore, Hutchinson (1957) considered that the environmental factors essential for the existence of a species could be defined as the axes of a multidimensional space. Following this concept, the environmental 
space occupied by PSN was determined using a two-step procedure:

Step 1: A standardized Principal Component Analysis (PCA) was applied to assess the main variability of environmental data along a reduced number of axes. The PCA analysis integrated the environmental data from the six bays from 2003 to 2012 and included the following variables: temperature, salinity, PAR, turbidity, nutrient concentrations (N, P, Si) and ratios $(\mathrm{Si} / \mathrm{N} / \mathrm{P})$. Previously to the PCA, particular care was given to select samples with sufficient nutrient data, and the remaining missing data from this selection were imputed as previously mentioned, using the missMDA package. Data kept for the niche analysis amounted to 660 samples, of which $75 \%$ came from the Quiberon and Seine bays. All years, from 2003 to 2012, and all months were represented in the analysis. Data selected for the PCA for Concarneau bay, Saint Brieuc Bay and the Pertuis Breton only concerned years 2007 to 2012, as nutrient analysis only started in 2007 in these bays, via the European Water Framework Directive protocols. However the Quiberon, Seine and Brest bays have maintained a constant effort in nutrient sampling since 2003. Consequently, data from before 2007 used in this analysis came from these three bays only. Environmental data were well distributed throughout the year, except for Saint Brieuc bay and the Pertuis Breton, where only winter data were available for this analysis.

Step 2: A kernel density calculation, weighed by corresponding PSN $\log _{10}$ abundance, was then applied to the first plan of the PCA. This method revealed areas of the plan where the highest abundances were observed, highlighting the most favourable combination of environmental conditions for PSN to bloom. Out of these highest abundances, the $5^{\text {th }}$ percentiles were then extracted for each environmental factor in order to determine the ecological niche of PSN.

\section{Results}




\subsection{Seasonal patterns of environmental parameters and phytoplankton}

The 6 bays displayed very similar seasonal patterns regarding temperature and cumulated PAR, with maxima being recorded respectively in August and June (Fig. 3A). The highest temperature and cumulated PAR medians were observed in the Pertuis Breton with respectively $21.0^{\circ} \mathrm{C}$ and $35.310^{3} \mathrm{~W} \mathrm{~m}^{-2}$. PAR maxima values were relatively similar in the 5 other sites. Some differences were nevertheless observed regarding temperature, particularly during summer. The Seine bay exhibited higher water temperature compared to the other sites (except Pertuis Breton), with a high interannual variability (Fig. 3B). In Concarneau Bay a decrease in water temperature was observed between June and July.

With respect to salinity, turbidity and phytoplankton biomass, the six bays showed very distinct seasonal patterns and amplitudes (Fig. 3A). In the Seine bay, salinity is relatively low throughout the year, with median ranging from 31.9 in March to 33.0 in October. Turbidity was relatively high in this bay, with maximum values being commonly observed in winter. Out of the six study sites, the Seine bay exhibited the highest phytoplankton biomass (median: 4.12 $\mu \mathrm{g} \mathrm{l}^{-1}$, Fig 3B and Table 2). Phytoplankton blooms start in February/March and the highest Chl $a$ concentrations were commonly observed from March to September. Seasonal dynamics of salinity, turbidity and phytoplankton biomass revealed themselves to be highly variable at the interannual time-scale in this semi-enclosed bay (Fig.3B).

The Saint Brieuc bay is host to more oceanic conditions, characterized by a constant and relatively high salinity (i.e. 34.8 to 35 ), low turbidity and low phytoplankton biomass. Moreover, among the 6 bays Saint Brieuc exhibited the lowest phytoplankton biomass, with maximum monthly Chl $a$ remaining below $2.5 \mu \mathrm{g} \mathrm{l}^{-1}$ in May.

In the Brest bay, salinity increased from 33.6 in March to 35.0 in August and turbidity remains very low (i.e $<2$ NTU) throughout the year (Fig. 2A). Phytoplankton blooms occured from March to September, with the highest monthly Chl $a$ concentrations being recorded in 
$\operatorname{May}\left(3.0 \mu \mathrm{g} \mathrm{l}^{-1}\right)$.

Quiberon and Concarneau bays displayed similar seasonal patterns. Salinity regularly increased from March and reached its highest values in August. Turbidity decreased from February to reach very low level in April. Phytoplankton biomass started increasing in March and reached the highest level in May. Some differences in terms of amplitude were nevertheless observed between these two sites, with Quiberon bay displaying a lower salinity, higher turbidity and higher phytoplankton biomass than Concarneau bay.

The strongest salinity variations were observed in the Pertuis Breton, where salinity increased from 30.0 in January to 35.0 in August (Fig. 3A). The highest turbidity levels were recorded in this shallow bay with the highest levels (i.e. $>15$ NTU) being observed from December to April. Phytoplankton bloom was observed in March with Chl $a$ concentrations remaining relatively high until September.

\subsection{Pseudo-nitzschia blooms along the Atlantic and English Channel coasts of France}

\subsubsection{Seasonal dynamics of Pseudo-nitzschia blooms}

The genus Pseudo-nitzschia was observed from March to November in the six study sites (Fig. 4A). Considering seasonal patterns as well as the amplitude of PSN blooms, three groups of bays were identified.

The highest PSN abundances were observed in Quiberon and Concarneau bays. Blooms occured as of March and reached their maxima in June. PSN Abundances decreased quickly thereafterin Quiberon, to reach very low values in July. In contrast, abundances remained relatively high in Concarneau throughout the summer and a second bloom was generally observed in September at this sampling site.

In the Seine and Brest bays, the intensity of PSN blooms was lower, with a maxima commonly reached in May. Abundances remained relatively high until July in Brest bay, 
whereas a s low decrease was observed in the Seine bay. A secondary bloom could be observed at both sampling sites: in August in the Seine bay and in September in the Brest bay. Saint Brieuc and the Pertuis Breton exhibited very low PSN abundances throughout the year compared to the four other sites. Maxima were observed in May in Saint Brieuc and in May-June in the Pertuis Breton.

As shown in the Figure4B, the intensity of PSN blooms may greatly vary from one year to another for each of the study sites. This variability was particularly high in the Concarneau, Quiberon and Seine bays. The highest variability of PSN abundances was observed in June in the Quiberon and Concarneau bays.

\subsubsection{Interannual variability of Pseudo-nitzschia blooms}

Figure 5 shows Pseudo-nitzschia spp. abundances at the 6 sampling sites over the1995 to 2012 period (data were not available before 1997 for the Seine bay).

Since 1995, high PSN abundances were consistently observed in Quiberon and Concarneau bays. Concarneau bay was the most concerned by PSN blooms, as abundances exceeded the sanitary threshold of $1 \times 10^{5}$ cells $1^{-1}$ every year. Moreover, in 2006 a nd 2008 a bundances reached the highest values, with $9 \times 10^{6}$ cells $1^{-1}$ and $14 \times 10^{6}$ cells $1^{-1}$ respectively. Very high abundances were recorded every year in Quiberon bay (Fig. 5), except in 2003, 2006, 2007 and 2010 when PSN abundances remained below $1 \times 10^{6}$ cells $1^{-1}$ (Fig.5).

In the Brest and Seine bays, PSN blooms were less intense than those observed in the Concarneau and Quiberon bays. In the Brest bay cell numbers exceeded the sanitary threshold in June 2004, 2007, 2009, and more than $10^{6}$ cells $1^{-1}$ were observed in June 2008. In the Seine bay, except in 2010 a nd 2011 when low abundances were observed, since 2003 PSN abundances have regularly exceeded the sanitary threshold. The interannual variability was particularly high in the Seine bay. The highest abundances (i.e. $>10^{6}$ cells $1^{-1}$ ) were recorded 
in May-June 2003, 2005 and 2009. In 2005 and 2012, the bloom was particularly long as PSN abundances remained high from April to August (Fig. 5).

In Saint Brieuc bay PSN abundances rarely exceeded the sanitary threshold. The highest abundances were recorded in May 2007 and 2008, with respectively $1.33 \times 10^{5}$ and $1.11 \times 10^{5}$ cells $1^{-1}$ (Fig. 5).

In the Pertuis Breton, except in 2006 and 2010 when PSN abundances reached the highest values of $1.2 \times 10^{5}$ cells $1^{-1}$ and $7.7 \times 10^{5}$ cells $1^{-1}$ respectively, the threshold of $1 \times 10^{5}$ cells $1^{-1}$ was never reached in 18 years of monitoring. While the highest PSN abundances were usually recorded in May-June (Fig. 4A), in 2010 PSN bloom occurred in March. A second bloom of PSN was observed in May-June following the exceptional and early bloom of March 2010 (Fig. 5).

\subsubsection{Pseudo-nitzschia within the phytoplankton community}

A Principal Component Analysis (PCA) was performed on phytoplankton biodiversity indices and PSN descriptors to assess the differences and similarities regarding the structure of the phytoplankton communities during Pseudo-nitzschia blooms in the different bays (Fig.6A). The first two axes explain nearly $48 \%$ of the variance. Axis $1(28.02 \%)$ is mainly structured by PSN descriptors such as the PSN-rank (PSN-Rank: 68.7\%; $p<0.0001$ ), PSN frequency within the community (\%PSN: 74.3\%; $<<0.0001)$ and PSN abundance (PSN: $61.7 \% ; p<0.0001$ ). The second axis is explained by the total phytoplankton abundance (TOT: $67.2 \% ; p<0.0001)$ and the richness of the phytoplankton community (S: $57.6 \% ; p<0.0001$ ).

Three groups of sampling sites were identified along the axis 1 (Fig. 6B). Located on the left side of the axis 1, Saint Brieuc bay and Pertuis Breton are characterized by low absolute and relative abundances of $P S N$, which never dominate the phytoplankton community (i.e. higher rank). In contrast, Concarneau and Quiberon bays, located on the right hand side of 
axis 1, displayed higher absolute and relative abundances of PSN, where it occupied a lower rank within the phytoplankton community. The Seine and Brest bays did not show any significant different from each other for these descriptors and were not well discriminated along the first axis.

\subsubsection{Ecological niche of Pseudo-nitzschia spp.}

PCA on environmental variables corresponds to the first step in determining the ecological niche of Pseudo-nitzschia. As shown on Figure 7, the first two axes, representing $56 \%$ of the explained variability, showed the seasonal patterns of environmental variables: (i) high nutrient concentration and high turbidity during the autumn-winter period, corresponding to well-mixed conditions and high freshwater input, i.e. high turbidity and nutrient concentration, on the right side of the first axis and (ii) a decrease in nutrient concentration over the spring and summer when the water temperature and irradiance increase, on the left side of the first axis. While the second axis of the PCA is mainly driven by the N/P ratio, $\mathrm{Si} / \mathrm{N}$ and $\mathrm{Si} / \mathrm{P}$ ratios are not well represented on the first two axis of the analysis $\left(\cos ^{2}{ }_{S i / N}=3.7 * 1 \mathrm{e}-\right.$ $2, \cos _{S i / P}^{2}=6.05 * 1 \mathrm{e}-5$, where $\cos ^{2}$ measures the quality of a variable representation on the factor map).

The niche approach used here provided evidence of the environmental occupancy of Pseudonitzschia through the analysis of their occurrences. A main region of dense occurrence (weighted by the abundance) was observed on the left side of the PCA analysis and mainly over the first axis (Fig. 7). PSN exhibited a niche characterized by a relatively high irradiance, water temperature and salinity and conversely, low nutrient concentration and turbidity, which corresponds to spring/summer conditions.

This visual impression was confirmed by the extraction of the occurrences with the highest densities (defined as the 5\% contour, see Fig. 7, Table 3). The 5\% PSN highest abundance 
window displayed an ecological niche (Table 3) corresponding to the highest salinity waters (not less than 34.02 ), relatively high water temperature (between 15.9 and $17.9^{\circ} \mathrm{C}$ ) and irradiance (between 21791 and $28227 \mathrm{Wm}^{-2}$ ). This confirmed that PSN bloom occur mostly during spring and early summer time. Turbidity should not exceed 1.35 NTU. Nutrient values for the $5 \%$ window showed minimum values $\left(\mathrm{P}=0.03 \mu \mathrm{mol}^{-1}, \mathrm{Si}=0.33 \mu \mathrm{mol} \mathrm{l}^{-1}, \mathrm{~N}=0.06\right.$ $\mu \mathrm{mol} \mathrm{l}^{-1}$ ) corresponding to relatively low concentrations, particularly for $\mathrm{N}$. The N/P ratio for the 5\% window showed values lower than the Redfield ratio (16) and the second axis did not appear to have any impact on the maximum PSN abundances, even if there was slightly more PSN data on the upper second axis (higher N/P).

3

King scallop contamination by domoic acid along the French Atlantic and English

\section{Channel coasts}

\subsubsection{Interannual variability of toxic events}

The first king scallop contaminations by domoic acid were recorded in 2004 in the Seine and Brest bays (Fig.8A). Since then, ASP events in Pecten maximus fishing grounds have become more frequent and widespread along the French coast. At the interannual time scale the frequency of these toxic events differs widely between sites (Fig. 8A).

Saint Brieuc bay was never affected by ASP events; DA concentration in king scallops never exceeded the sanitary threshold (i.e. $20 \mu \mathrm{g} \mathrm{DA} \mathrm{g}^{-1} \mathrm{ww}$ ) and STI remained negligible over the study period $\left(<3 \mu \mathrm{g}\right.$ DA g $\left.{ }^{-1} \mathrm{y}^{-1} \mathrm{ww} \mathrm{y}^{-1}\right)$. In the Pertuis Breton, high STI was only recorded in 2010 (i.e. $194 \mu \mathrm{g} \mathrm{DA} \mathrm{g}^{-1} \mathrm{wwy}^{-1}$ ).

The Brest and Seine bays were irregularly concerned by DA contamination. High STI values were recorded in 2004, 2007, 2008 and 2009 in the Brest bay with a maximum of 180 $\mu \mathrm{g} \mathrm{DA} \mathrm{g}^{-1} \mathrm{wwy}^{-1}$ in 2007. In the Seine bay STI were particularly high in 2004, 2005, 2011 and 
highest values were recorded in $2012\left(287 \mu \mathrm{g} \mathrm{DA} \mathrm{g}^{-1} \mathrm{wwy}^{-1}\right)$.

Concarneau and Quiberon bays were both regularly impacted by significant DA contaminations as high STI have been observed each year since 2006 and 2004 respectively. An exceptional contamination in terms of intensity and spatial extension was observed in 2010 in the bay of Biscay (i.e. the Pertuis Breton, Quiberon bay and Concarneau bay) with a maximum STI of $445 \mu \mathrm{g} \mathrm{DA} \mathrm{g}^{-1} \mathrm{wwy}^{-1}$ in Quiberon bay.

\subsubsection{STI and annual maximum Pseudo-nitzschia spp. abundance}

STI calculated over the 2003-2012 period in each study sites was plotted against annual maximum PSN abundance (Fig.8B) in order to investigate a possible link between PSN bloom intensity and STI.

In Saint Brieuc bay, over the study period maximum concentrations of PSN remained below, or very close, to the sanitary threshold (i.e. $<10^{5}$ cellsL ${ }^{-1}$ ) and negligible STI were always observed. Similarly low maximal concentrations of PSN and low STI were usually recorded in the Pertuis Breton. Nevertheless, in 2010 maximum PSN abundance greatly exceeded the sanitary threshold in the Pertuis Breton and the highest STI was recorded this particular year. In 2011 and 2012, while STI remained low, annual maximum abundance of PSN was relatively low.

In the Brest and Seine bays, high STI were intermittently observed. Since 2004, high STI always matched high max PSN in the Brest bay. In contrast, in the Seine bay max PSN regularly exceed the sanitary threshold without major STI levels.

Prior to 2004 in Concarneau and to 2006 in Quiberon, high max PSN were observed in both bays without high STI. Since then, PSN concentrations have always reached values above $10^{5} \mathrm{cellsl}^{-1}$ and high STI were regularly observed in both bays. 


\section{Discussion}

\subsection{Seasonal patterns of Pseudo-nitzschia sp. blooms along the French coast}

The genus Pseudo-nitzschia was a common member of the diatom community and was represented throughout the year at the six study sites (Fig. 4). In contrast with previous observations suggesting that PSN blooms were mainly observed from January to May in European waters (Hasle et al., 1996; Lelong et al., 2012), results show that PSN blooms occured from May to September along the French Atlantic and English Channel coasts. A first bloom was observed in spring (i.e. May/June) in the six study sites and was followed by another smaller peak at the end of summer in the Concarneau, Brest and Seine bays (Fig.4). These results were congruent with previous studies reporting PSN blooms in spring and at the end of the summer in very diverse ecosystems such as the Gulf of Mexico (Dortch et al., 1997; Parsons and Dortch, 2002; Parsons et al., 2013), western Scottish waters (Fehling et al., 2006), the North Sea (Bresnan et al., 2015) or the Mediterranean Sea (Mercado et al., 2005).

Despite the diversity of environmental constraints encountered among the six bays, a clear synchronism was nevertheless observed regarding Pseudo-nitzschia spp. spring blooms, suggesting that large-scale factors might trigger PSN blooms along the coast during this period. Much of the seasonal variability of PSN blooms has indeed been attributed to regular shifts in environmental conditions such as wind, irradiance, temperature or river flow (e.g. Trainer et al., 2012 a nd references therein). In this study, the PSN spring blooms started between March (for Quiberon and Concarneau bays) and April (other bays) under various conditions of salinity (and related river flow), turbidity and phytoplankton biomass (Table 2; Fig. 2A). However, similar ranges of photosynthetic active radiation (PAR) and relatively similar ranges of temperature were commonly observed along the coast during this period. These observations suggest that irradiance and temperature may play a major role on PSN bloom initiation in spring along the French Atlantic and English Channel coasts. A first spring 
501

502

503

504

505

506

507

508

509

510

511

512

513

514

515

516

517

518

519

520

521

522

523

524

525

PSN maximum was reached between May and June for all sites corresponding to maximum PAR but not to maximum temperature (Fig.2). This was confirmed by the niche analysis (Fig. 7, Table 3).

Regarding nutrient availability, although the lack of regular data made it difficult to draw conclusions, March/April are known to be favorable months for diatom growth as high winter nutrient concentrations were still substantial and day length started to increase to increase (Gohin et al 2003).

In contrast, the discrepancy observed among sampling sites regarding the occurrence of a second Pseudo-nitzschia spp. bloom at the end of summer suggests that these late blooms were driven by more local meteorological phenomenon and, as such, should be more strongly related to the intrinsic environmental characteristics of each bay. Moreover, the occurrence of these late blooms was highly variable at the interannual time scale for the 3 bays concerned (i.e. Seine, Brest and Concarneau bays; Fig.4), supporting the hypothesis of non-recurring local events controlling PSN blooms during this period. The Seine and Brest bays are wellmixed semi-enclosed areas receiving direct freshwater inputs which are highly variable during the summer. These freshwater inputs bring an influx of nutrients during the season when they are naturally at their lowest in the marine environment, and could therefore stimulate late PSN blooms as previously shown in the Seine bay (Klein et al., 2010) and in other coastal areas (e.g. Bates et al., 1996;Schnetzer et al., 2007; Liefer et al., 2013). Strong wind events that mix a stratified water column and transitory upwelling are also responsible for nutrient enrichment and have been shown to trigger PSN blooms in many coastal areas (e.g. Dortch et al., 1997; Lund-Hansen et al., 2004; Trainer et al., 2007; Schnetzer et al., 2013). This may also be the case for the triggering of the PSN bloom observed in September in Concarneau bay. Results underline the difficulty in fully assessing the environmental cues that control PSN blooms that can be unique to the bays where they occur. Moreover, additional environmental data, such as 
526

527

528

529

530

531

532

533

534

535

536

537

538

539

540

541

542

543

544

545

546

547

548

549

550

nutrient concentrations are lacking and would be necessary in order to fully understand the dynamics of PSN blooms along the French Atlantic and English Channel coasts. Specific seasonal surveys are needed to thoroughly identify the main factors controlling Pseudonitzschia spp. blooms within each bay.

\subsection{Pseudo-nitzschia spp. blooms and ASP event frequency along the French coast}

The magnitude and characteristics of Pseudo-nitzschia spp. blooms as well as the frequency of ASP events greatly varied between the bays and the 3 groups identified (Fig. 6 and Fig. 8A). The strongest PSN blooms occured in the Quiberon and Concarneau bays, where the highest abundances were recorded and where this genus recurrently dominated the phytoplankton community (Fig. 6). Furthermore, king scallop fishing grounds were also chronically impacted by domoic acid contamination in both these bays: since $2004 \mathrm{in}$ Concarneau and 2006 in Quiberon (Fig. 8). These results suggest recurring local events to be at play in stimulating toxic PSN blooms every year in the Northern Bay of Biscay. The coincidence of PSN dominance and ASP events has been shown in the North Sea (Bresnan et al. 2015). Indeed, the Scottish site where diatom cell abundance was dominated by the PSN was affected by toxicity, whereas in German sites, where diatom blooms were not dominated by PSN no toxic events have been observed.

At the other end of the spectrum are the Pertuis Breton and Saint Brieuc bay, where ASP events were shown to be scarce and where PSN blooms were, most of the time, very limited in terms of absolute and relative abundance (Fig 6 and Fig. 8). Despite very distinct environmental constraints, this implies the prevalence of unfavorable conditions for toxic PSN blooms in both these coastal ecosystems. Between these two extremes in PSN bloom magnitudes as well as ASP event frequency, the Seine and Brest bays exhibited relatively high Pseudo-nitzschia spp. abundances, and king scallops fishing grounds were intermittently 
551

552

553

554

555

556

557

558

559

560

561

562

563

564

565

566

567

568

569

570

571

572

573

574

575

affected by domoic acid contamination in both these bays. This suggests that non-recurring local events may control toxic PSN bloom outbreaks in these well-mixed shallow bays.

These results suggest a strong link between the magnitude of Pseudo-nitzschia spp. blooms, the importance of this genus within the phytoplankton community and the frequency of ASP events impacting king scallop fishing grounds. In addition, the discrepancies and similarities of environmental constraints among and within the different groups of bays could give rise to a hypothesis regarding the frequency of ASP events along the coast.

\subsubsection{Chronic ASP events}

Located in the northern Bay of Biscay, Concarneau and Quiberon bays have emerged as perennial "hot spots" for Pseudo-nitzschia spp. blooms and ASP events along the French coast. In winter and early spring, this coastal zone receives large freshwater inputs from the Loire and Vilaine rivers (e.g. Loyer et al., 2006; Guillaud et al., 2008), whilst in summer, local upwelling can form along the coast following W/NW wind episodes (Lazure and Jégou 1998; Puillat et al., 2004, 2006). The combination and/or the succession of both these hydrological phenomena could trigger intense and recurrent toxic PSN blooms in both these bays. Indeed, nutrient inputs from several sources, including riverine inputs and upwelling or mixing events, have been shown to stimulate PSN blooms in a variety of coastal areas (e.g. Trainer et al., 2000; Parsons et al., 2002; Kudela et al., 2005; Anderson et al., 2008) when temperature and irradiance are favorable. In particular, the unbalance in the delivery of nitrogen with respect to silica and/or phosphorus has been shown to be associated with DA production (Pan et al., 1996; Fehling et al., 2004; Parsons and Dortch, 2002; Anderson et al., 2006; Trainer et al., 2007). This is the case particularly for the Quiberon and Concarneau bays, and in fact for all bays excepting Saint Brieuc which hasn't shown toxic PSN, figure 2. In the northern Bay of Biscay, the succession, or combined effect, of freshwater inputs from the Loire and Vilaine 
576

577

578

579

580

581

582

583

584

585

586

587

588

589

590

591

592

593

594

595

596

597

598

599

600

rivers and local upwelling may therefore contribute to the recurrent development of toxic Pseudo-nitzschia blooms and contamination of king scallop fishing grounds in these open bays.

\subsubsection{Episodic ASP events}

The Seine and Brest bays are well-mixed semi-enclosed areas receiving direct freshwater inputs. Anthropogenic nutrients have been shown to strongly affect the functioning in both these eutrophic coastal zones (e.g. Del Amo et al., 1997; Cugier et al., 2005; Romero et al., 2013) and fluxes of silicate, phosphate and nitrate into the bays are strongly controlled by river discharge at the interannual and seasonal scales (e.g. Billen et al., 2001; Romero et al., 2013). In addition, in these well-mixed shallow bays benthic fluxes may also influence phytoplankton community structure. Previous studies carried out in the Brest bay have shown the role of benthic fluxes of dissolved silicic acid in controlling the structure of the phytoplankton community (Del Amo et al., 1997; Fouillaron et al., 2007). Many chemical, physical and biological processes may influence the nutrient supply from the sediments to the pelagic zone (Andrieux-Loyer et al, 2008; Sakamaki et al., 2006) and this autochthonous nutrient supply is likely to vary at both the seasonal and interannual scales. N/P ratios are high in winter during flood events (over the Redfield ratio). This emphasizes observations made by Klein et al (2010), who in September 2007 reported a bloom dominated by P. australis and associated with significant levels of particulate domoic acid. This toxic bloom occurred after high nitrogen inputs following a sudden rainfall event resulting in a potential limitation by $\mathrm{Si}$ and/or P.

\subsubsection{Exceptional ASP events}

The same causes may explain the exceptional ASP event observed in 2010 in the Pertuis 
601 Breton and in the Northern Bay of Biscay (Fig. 6). In winter 2010 the European windstorm 602 "Xynthia" hit the French coast on the $28^{\text {th }}$ of February, causing an exceptional storm surge

603

604

605

606

607

608

609

610

611

612

613

614

615

616

617

618

619

620

621

622

623

624

625 and consequent flooding along the Southwestern part of the French Atlantic coast (Bertin et al, 2014). Sea water flooding as well as high precipitation may have led to unusually high nutrient loads which could have triggered the intense bloom of PSN observed as early as March in the Pertuis Breton and the subsequent contamination of king scallop fishing grounds (Fig.8). Moreover, the highly toxic species Pseudo-nitzschia australis was identified in March 2010 in the Pertuis Breton (Nézan et al., 2010). This environmental context has already been described in other areas, where PSN toxic blooms have appeared after a period of heavy rainfall resulting in nutrient-rich freshwater inputs, in places such as the eastern Canadian coast (Smith et al., 1990; Bates et al., 1998b), the northern Gulf of Mexico (Parsons et al., 2013; Macintyre et al., 2011), Monterey Bay (Bird and Wright, 1989), the Californian coast (Trainer et al., 2000), San Diego bay (Busse et al., 2006) and the Gulf of Kalloni in Greece in 2004 (Spatharis et al., 2007). While nutrient concentration values in the water column following windstorm Xynthia are lacking to confirm this hypothesis, results show that major climatic events can trigger toxic Pseudo-nitzschia outbreaks in previously non-impacted coastal waters. In addition, they show that large-scale climatic events could stimulate toxic Pseudo-nitzschia blooms over a large spatial scale and impact king scallop fisheries all along the Bay of Biscay coastline. In the context of sea level rise and increases in extreme weather events such as winter storms, an improved knowledge of the potential consequences of largescale climatic events on toxic phytoplankton blooms is an absolute prerequisite for risk assessment.

\subsection{Environmental control of toxic Pseudo-nitzschia spp. blooms and ASP events}

Environmental pressures act both on species phenology and on toxin synthesis (Trainer et 
626

627

628

629

630

631

632

633

634

635

636

637

638

639

640

641

642

643

644

645

646

647

648

649

650

al., 2012). Nitrogen enrichment and silicate or phosphorus limitation are known to stimulate DA production (Bates et al., 1998a; Fehling et al., 2004b; Parsons et al. 2013; Van de Waal et al. 2014). Among the different environmental factors that have been shown to be associated with toxic Pseudo-nitzschia blooms (e.g. Trainer et al., 2012; Lelong et al., 2012 a nd references therein), different degrees of nitrogen enrichment from river discharge, vertical mixing or upwelling could partly explain the discrepancies observed along the French Atlantic and English Channel coasts, regarding the magnitude of Pseudo-nitzschia blooms and the frequency of ASP events. Indeed, results have shown that ASP events tend to be more frequent in bays strongly influenced by riverine inputs and/or transitional upwelling such as the Concarneau, Quiberon, Brest and Seine bays. In contrast, in the Saint Brieuc bay where freshwater inputs are very limited, no ASP event has been observed in the 2003 to 2012 period in local king scallop fishing grounds. This observation tends to support the hypothesis of an increasing risk of toxic Pseudo-nitzschia outbreaks along a gradient of nutrient inputs from anthropogenic or natural origins..

However, the lack of intense PSN blooms in the Pertuis Breton under typical environmental conditions tends to invalidate this hypothesis. Indeed, despite substantial freshwater inputs from the Lay $\left(20 \mathrm{~m}^{3} \mathrm{~s}^{-1}\right)$ and Seudre-Niortaise rivers $\left(25 \mathrm{~m}^{3} \mathrm{~s}^{-1}\right)$, Pseudonitzschia abundances rarely exceed the sanitary threshold in the Pertuis Breton. King scallop stocks remained safe from domoic acid contamination, except in 2010 following the Xynthia windstorm. This suggests that other environmental factors could control the growth of Pseudo-nitzschia cells in this shallow embayment. In particular, this bay exhibited higher temperature, irradiance and turbidity than the five other sites (Fig. 2). Increased temperature and irradiance have been shown to stimulate growth rates and DA production in Pseudonitzschia australis (Thorel et al., 2014). The high turbidity observed in this shallow bay especially during the spring was likely to reduce light availability and therefore limit the 
651

652

653

654

655

656

657

658

659

660

661

662

663

664

665

666

667

668

669

670

671

672

673

674

675

growth of Pseudo-nitzschia as well as DA production.

While the comparison of PSN bloom magnitudes and ASP event frequencies in six contrasted ecosystems allowed us to formulate some hypotheses regarding the environmental factors driving the discrepancies observed along the coast, nutrient concentration data are crucially lacking to validate this hypothesis. Systematic sampling for nutrient concentrations during routine monitoring surveys is an absolute prerequisite to further assessing the role of nutrients on toxic PSN blooms along the French Atlantic and English Channel coasts..

Different hypotheses could be raised to explain the discrepancies between toxicity and yearly maximum PSN. While several PSN blooms may occur over a year (Fig.5), not all of them necessarily lead to scallop contamination, depending on: i) the presence and dynamics of toxic Pseudo-nitzschia species and environmental conditions favoring DA synthesis in toxic species and (ii) the pathway between PSN toxic blooms to king scallop contamination, considering transport and sedimentation.

\subsection{A matter of diversity}

The Pseudo-nitzschia genus was common member of the phytoplankton community and was present in the water column from spring to autumn in the different studied sites. The risk period for king scallop fishing grounds extends from March to September depending on the bay considered. The sampling frequency as well as the strategy implemented for the survey of king scallop contamination by DA, did not permit an accurate identification of the date of king scallop contamination over this long timeframe. It was therefore impossible to precisely identify the bloom responsible for a given ASP event, or which species was responsible for this bloom.

Thirteen different Pseudo-nitzschia species have been identified along the French coast (Belin et al 2012). Considering the difficulty in precisely identifying Pseudo-nitzschia species 
676

677

678

679

680

681

682

683

684

685

686

687

688

689

690

691

692

693

694

695

696

697

698

699

700

under light microscopy, most data only refers to the genus level and the assumptions made previously only concern the genus Pseudo-nitzschia spp.. Among the different species identified along the French coast, the highly toxic species $P$. australis and also P. multiseries have been linked to major ASP events along the French coast (Nézan et al., 2006, 2010).Several species of PSN, with different optimal growth constraints might thrive over the year, e.g. six species have been identified in the Seine bay over an entire year (Klein et al., 2010). In Stonehaven (Scotland), Bresnan et al (2015) showed that, P. australis and P. seriata, which are highly toxic, were only observed in late summer and autumn whereas in spring $P$. delicatissima, P. pseudodelicatisima and P. fraudulenta were dominant. As different species can demonstrate distinct correlations with environmental factors (e.g. Trainer et al., 2012; Lelong et al., 2012), further research is needed to identify the different species of PSN succeeding over the year within each bay in order to identify the environmental cues triggering their growth and toxicity.

\subsection{King scallop contamination vector by domoic acid}

Contamination of benthic bivalves depends on a $\mathrm{v}$ ariety of physical (e.g. transport, sedimentation of PSN) and biological (e.g. physiological state, cellular DA levels) parameters. In particular, the transport and sedimentation of PSN blooms over king scallop fishing grounds may be particularly important in bays where king scallop beds are located far from phytoplankton monitoring sampling points, such as in the Seine bay. The optimal way to accurately identify the timing of toxic Pseudo-nitzschia blooms, which is an absolute prerequisite to identify the triggering factors, would be to carry out synchronized measurements of (i) Pseudo-nitzschia spp. abundance, (ii) domoic acid concentrations in the water column and in the vicinity of king scallop fishing grounds and (iii) DA concentrations in king scallops. 
Another source of discrepancy between PSN abundance and STI could be the origin of contamination. Indeed, the accumulation of dense PSN biomass on the seafloor provides a vector for DA accumulation in a variety of benthic fauna (Lefebvre et al. 2002b; Kvitek et al., 2008; Sekula-Wood et al., 2009). As significant levels of domoic acid have been measured in sediment traps long after PSN blooms have died out on the surface (e.g. Sekula-Wood et al., 2009), the period of king scallop contamination is therefore likely to extend well beyond the period of PSN blooms. If contaminated sediments became re-suspended following mixing events (e.g. storm, spring tides currents, dredging...) they could constitute a 'secondary' source of contamination for king scallops. An improved knowledge of contamination processes in king scallops as well as additional data regarding the wane of domoic acid in the sediment are crucially needed to fully assess the threat of toxic Pseudo-nitzschia blooms on Pecten maximus fisheries.

\section{Conclusion}

This work is one of the first studies describing Pseudo-nitzschia spp. blooms and Amnesic Shellfish Poisoning (ASP) events in Pecten maximus fishing grounds along the French Atlantic and English Channel coasts. The genus Pseudo-nitzschia is a common member of the diatom community which can bloom from May to September along the coast. The magnitude and characteristic of Pseudo-nitzschia spp. blooms as well as the frequency of ASP events greatly vary along the coast. Different degrees of nitrogen enrichment from river discharge, vertical mixing or upwelling could partly explain the discrepancies observed along the French Atlantic and English Channel coasts. Results suggest the frequency of ASP events, i.e. chronic, episodic and exceptional, to be linked to the frequency of physical and hydrological processes (i.e. river discharge, upwelling, vertical mixing) controlling nutrient ratios over the seasonal and interannual time scale. In addition, this study has shown that large-scale climatic 
events, such as the 'Xynthia' windstorm in 2010, could stimulate toxic Pseudo-nitzschia blooms and impact king scallop fisheries over a large spatial scale. In addition, these results highlight the difficulty in fully assessing the environmental cues that control PSN blooms that can be unique to the bays where they occur. Additional environmental data, such as nutrient concentrations are lacking to fully understand the dynamics of PSN blooms along the French Atlantic and English Channel coasts. Specific seasonal surveys are therefore needed to thoroughly identify the main factors controlling Pseudo-nitzschia spp. blooms within each bay.

Finally, different climate change scenarios (i.e. sea level rise, increases in storminess, deep changes in river discharge and increased anthropogenic pressure along river watersheds) make it necessary to both improve our knowledge of the environmental factors controlling toxic phytoplankton blooms and to ameliorate surveys, in order to provide informationfor risk management in exploited coastal waters.

\section{Acknowledgments}

The authors thank the REPHY and RHLN monitoring networks for providing all data. The authors also wish to thank Pierre Bodenes for his help in figure designing and Amelia Curd for her help in improving the English. The authors are also grateful to reviewers for their reading and constructive comments. The RHLN monitoring network is funded by l'Agence de l'Eau Seine-Normandie (AESN) and the Région Basse Normandie.

\section{References}

Amzil, Z., Fresnel, J., Le Gal, D., Billard, C., 2001. Domoic acid accumulation in French shellfish in relation to toxic species of Pseudo-nitzschia multiseries and $P$. pseudodelicatissima. Toxicon 39, 1245-1251. 
752 Anderson, D.M., Burkholder, J.M., Cochlan, W.P., Gilbert, P.M., Gobler, C.J., Heil, C.A., 753 Kudela, R.M., Rensel, J.E.J., Townsend, D.W., Trainer, V.L., Vargo, G.A., 2008. Harmful 754 algal blomms and eutrophication: examinating linkages from selected coastal regions of the 755 United States. Harmful Algae 8, 39-53.

Andrieux-Loyer, F., Philippon, X., Bally, G., Kerouel, R., Youenou, A., \& Le Grand, J.

758

759

(2008). Phosphorus dynamics and bioavailability in sediments of the Penzé Estuary (NW France): in relation to annual P-fluxes and occurrences of Alexandrium minutum. Biogeochemistry, 88(3), 213-231.

Arévalo, F.F., Bermudez de la Puente, M., Salgado, C., 1998. ASP toxicity in scallops: individual variability and distribution. In: Reguera, B., Blanco, J., Fernandez, M.L.,Wyatt, T. (Eds.), Harmful Algae. Xunta de Galicia and Intergovernmental Oceanographic Commission of UNESCO, Vigo, Spain, pp. 499-502.

Bargu, S., Silver, M.W., Ohman, M.D., Benitez-Nelson, C.R., Garrison, D.L., 2012. Mystery behind Hitchcock's birds. Nat. Geosci. 5, 2-3.

Bates, S. S., Leger, C., Smith, K. M., 1996. Domoic acid production by the diatom Pseudonitzschia multiseries as a function of division rate in silicate-limited chemostat culture. Intergovernmental Oceanographic Commission of UNESCO, Paris, France, pp. 163-166.

Bates S.S., 1998. Ecophysiology and metabolism of ASP toxin production. In: Anderson, D.M., A. D. Cembella, A.D., Hallegraeff, G. M. (Eds.), Physiological ecology of Harmful 
algal blooms. NATO ASI Series 41. Springer, Berlin Heidelberg, New York, pp. pp. 405-426.

Bates, S.S., Garrison, D.L., Horner, R.A., 1998. Bloom dynamics and physiology of domoicacid-producing Pseudo-nitzschia species. In: Anderson, D.M., Cembella, A.D., Hallegraeff, G.M. (Eds.), Physiological ecology of Harmful algal blooms. NATO ASI Series 41. Springer, Berlin Heidelberg, New York, pp. 267-292.

Bates, S. S., Trainer, V. L., 2006. The ecology of harmful diatoms. In:Granéli, E., Turner, T., (Eds.), Ecology of Harmful Algae, Springer-Verlag, Berlin Heidelberg, pp. 81-93.

Belin, C., Amzil, Z., 2010. Phycotoxin monitoring in France: risk-based strategy and main results (2006-2008). ICMSS09 - Nantes, France - June 2009. $\underline{\text { http://archimer.ifremer.fr/doc/00077/18821 }}$

Belin, C., Chapelle, A., Delmas,D., Nézan, E, Siano, R. (2013). DYNAPSE : DYNAmiques des efflorescences et de la toxicité des espèces phytoplanctoniques nuisibles du genre PSEudo-nitzschia en région Loire-Bretagne. http://archimer.ifremer.fr/doc/00189/30035/

Berger, W.H., Parker, F.L., 1970. Diversity of planktonic Foraminifera in deep sea sediments. Science 168, 1345-1347.

Bertin, X., Bruneau, N., Breilh, J. F., Fortunato, A. B., \& Karpytchev, M. (2012). Importance of wave age and resonance in storm surges: The case Xynthia, Bay of Biscay. Ocean Modelling, 42, 16-30. 
801 Billen, G., Garnier, J., Ficht, A., Cun, C., 2001. Modeling the response of water quality in the 802 Seine river estuary to human activity in its watersheds over the last 50 years. Estuaries 24:

803

804

805

806

807

808

809

810

811

812

813

814

815

816

817

818

819

820

821

822

823 977-993.

Bird, C. J., Wright, J. L. C., 1989. The shellfish toxin domoic acid. World Aquacul.20(1), 4041.

Blanco, J., de la Puente, M. B., Arévalo, F., Salgado, C., and Moroño, Á., 2002. Depuration of mussels (Mytilus galloprovincialis) contaminated with domoic acid. Aquat. Living Resour.15(01), 53-60.

Bogan, Y.M., Harkin, A.L., Gillespie, J., Kennedy, D.J., Hess, P., Slater, J.W., 2007a. The influence of size on domoic acid concentration in king scallop, Pecten maximus (L.). Harmful Algae 6, 15-28.

Bogan, Y.M., Kennedy, D.J., Harkin, A.L., Gillespie, J., Vause, B.J., Beukers-Stewart, B.D., Hess, P., Slater, J.W., 2007b. Variation in domoic acid concentration in king scallop (Pecten maximus) from fishing grounds around the Isle of Man. Harmful Algae 6, 81-92.

Bresnan E., Kraberg A., Fraser S., Brown L., Hughes S., Wiltshire K.H., 2015. Diversity and seasonality of Pseudo-nizschia (Peragallo) at two North Sea time-series monitoring sites. Helgoland Marine Research, 69(2), 193-204 
827

Busse, L. B., Venrick, E. L., Antrobus, R., Miller, P. E., Vigilant, V., Silver, M. W., Prezelin, B. B., 2006. Domoic acid in phytoplankton and fish in San Diego, CA, USA. Harmful Algae, $5,91-101$

Campbell, D. A., Kelly, M. S., Busman, M., Bolch, C. J. S., Wiggins, E., Moeller, P. D. R., Shumway, S. E., 2001. Amnesic shellfish poisoning in the king scallop, Pecten maximus, from the west coast of Scotland. J. Shellfish Res., 20(1), 75-84.

Cugier P., Ménesguen A., Guillaud J.F., 2005. Three-dimensional (3D) ecological modelling of the Bay of Seine (English Channel, France). J. Sea Res., 54, 104-124.

Del Amo, Y., Queguiner, B., Treguer, P., Breton, H., Lampert, L., 1997. Impacts of highnitrate freshwater inputs on macrotidal ecosystems. II. Specific role of the silicic acid pump in the year-round dominance of diatoms in the Bay of Brest (France). Mar. Ecol. Progr. Ser. 161, $225-237$.

Dortch, Q., Robichaux, R., Pool, S., Milsted, D., Mire, G., Rabalais, N.N., Soniat, T.N., Fryxell, G.A., Turner, G.E., Parsons, M.L., 1997. Abundance and vertical flux of Pseudonitzschia in the northern Gulf of Mexico. Mar. Ecol. Prog. Ser. 146: 249-264.

Doucette, G., Maneiro, I., Riveiro, I., Svensen, C., 2006. Phycotoxin Pathways in Aquatic Food Webs: Transfer, Accumulation and Degradation. In: Granéli, P.D.E., Turner, P.D.J.T. (Eds.), Ecology of Harmful Algae, Springer-Verlag, Berlin Heidelberg, pp. 283-295. 
849 from the European Commission on marine biotoxins in shellfish-domoic acid. Eur. Food

850 Safety Authority J. 1181, 1-16 Available at

851 http://www.efsa.europa.eu/en/efsajournal/doc/1181.pdf

852

853 Fehling, J., Green, D.H., Davidson, K., Bolch, C.J., Bates, S.S., 2004a. Domoic acid 854 production by Pseudo-nitzschia seriata (Bacillariophyceae) in scottish waters. J. Phycol. 40, $855 \quad 622-630$.

856

857 Fehling, J., Davidson, K., Bolch, C.J., Bates, S.S., 2004b. Growth and domoic acid production 858 by Pseudo-nitzschia seriata (Bacillariophyceae) under phosphate and silicate limitation. J. 859 Phycol. 40, 674-683.

860

861 Fehling, J., Davidson, K., Bolch, C., Tett, P.,2006. Seasonality of Pseudo-nitzschia spp.(Bacillariophyceae) in western Scottish waters. Mar. Ecol. Prog. Ser.323, 91-105.

863

864 Fouillaron, P., Claquin, P., L’Helguen, S., Huonnic, P., Martin-Je'ze'quel, V., Masson, A., 865 Longphuirt, S., Pondaven, P., Thouzeau, G., Leynaert, A., 2007. Response of a phytoplankton 866 community to increased nutrient inputs: a mesocosm experiment in the Bay of Brest (France). 867 J. Exp. Mar. Biol. Ecol. 351, 188-198.

868

869 Fraga, S., Alvarez, M.J., Miguez, A., Fernandez, M.L., Costas, E., Lopez-Rodas, V., 1998. 870 Pseudo-nitzschia species isolated from Galician waters: toxicity, DNA content and lectin 871 binding assay. In: Reguera, B., Blanco, J., Fernandez, M.L., Wyatt, T. (Eds.), Harmful Algae. 872 Xunta de Galicia and Intergovernmental Oceanographic Commission of UNESCO, Vigo, 873 Spain, pp. 270-273. 
875 Frontier, S.,1985. Diversity and structure in aquatic ecosystems. Oceanogr. Mar. Biol. 23, $876 \quad 253-312$.

877

878 Gallacher, S., Howard, G., Hess, P., Mac Donald, E., Kelly, M.C., Bates, L.A., Brown, N., 879 MacKenzie, M., Gillibrand, P., Turrel, W.R., 2001. The occurrence of amnesic shellfish 880 poisons in Scottish waters. In: Hallegraeff, G.M., Blackburn, S.I., Bolch, C.J., Lewis, R.J. 881 (Eds.) Harmful Algae Blooms 2000. Paris: Intergovernmental Oceanographic Commission of UNESCO. pp. 30-33.

883

Garreau, P., 1993. Hydrodynamics of the North Brittany coast: a synoptic study. Oceanol. 885 Acta 16, 469-477.

886

887

Glibert, P. M., Anderson, D. M., Gentien, P., Granéli, E., Sellner, K. G., 2005. The global, 888 complex phenomena of harmful algal blooms. Oceanography 18, 136-147.

889

890 Gohin, F., Lampert, L., Guillaud, J. F., Herbland, A., \& Nézan, E., 2003. Satellite and in situ 891 observations of a late winter phytoplankton bloom, in the northern Bay of Biscay. Continental shelf research, 23(11), 1117-1141.

893

Guillaud, J.F., Andrieux, F., Menesguen, A., 2000. Biogeochemical modelling in the Bay of 895 Seine (France): an improvement by introducing phosphorus in nutrient cycles. J. Mar. Syst. 896 25, 369-386.

897

Hallegraeff, G.M., 1993. A review of harmful algal blooms and their apparent global increase. 
899

900

901

902

903

904

905

906

907

908

909

910

911

912

913

914

915

916

917

918

919

920

921

922

923

Phycologia 32, 79-99.

Hasle, G. R., Lange, C. B., Syvertsen, E. E., 1996. A review ofPseudo-nitzschia, with special reference to the Skagerrak, North Atlantic, and adjacent waters. Helgoländer Meeresuntersuchungen, 50(2), 131-175.

Hydes, D. J., Aoyama, M., Aminot, A., Bakker, K., Becker, S., Coverly, S., Daniel, A., Dickson, A. G., Grosso, O., Kerouel, R., van Oojen, J., Sato, K., Tanhua, T., Woodward, E. M. S., Zhang, J. Z., 2010 Determination of dissolved nutrients (N, P, Si) in seawater with high precision and inter-comparability using gas-segmented continuous flow analysers. In Hood, E. M., Sabine, C. L., Sloyan, B. M. (eds), The GO-SHIP Repeat Hydrography Manual: A collection of Expert Reports and Guidelines. IOCCP Report No. 14, ICPO Publication Series No. 134, pp. 1-87. http://www.go-ship.org/HydroMan.html

Hutchinson, G.E., 1957. Concluding Remarks. Cold Spring Harb. Symp. Quant. Biol. 22, 415-427. doi:10.1101/SQB.1957.022.01.039.

Jeffery, B., Barlow, T., Moizer, K., Paul, S., Boyle, C., 2004. Amnesic shellfish poison. Food Chem. Toxicol. 42(4), 545-557.

Josse, J., Chavent, M., Liquet, B., Husson, F., 2012. Handling Missing Values with Regularized Iterative Multiple Correspondence Analysis, J. Classif. 29, 91-116.

Kérouel, R., and Aminot, A., 1997 Fluorometric determination of ammonia in sea and estuarine waters by direct segmented flow analysis. Mar. Chem. 57, 265-275. 
925 Klein, C., Claquin, P., Bouchart, V., Le Roy, B., Véron, B., 2010. Dynamics of Pseudo926 nitzschia spp. and domoic acid production in a macrotidal ecosystem of the eastern English 927 Channel (Normandie, France), Harmful Algae 9, 218-226.

928

929 Kudela, R., Pitcher, G., Probyn, T., Figueiras, F., Moita, T., Trainer, V., 2005. Harmful algal 930 blooms in coastal upwelling systems. Oceanography (Wash DC) 18, 184-197.

931

932

Kvitek, R. G., Goldberg, J. D., Smith, G. J., Doucette, G. J., Silver, M. W., 2008. Domoic 933 acid contamination within eight representative species from the benthic food web of Monterey Bay, California, USA. Mar. Ecol. Progr. Ser.367, 35-47.

935

Lazure, P., Jégou, A. M., 1998. 3D modelling of seasonal evolution of Loire and Gironde 937 plumes on Biscay Bay continental shelf. Oceanol. Acta 21(2), 165-177.

938

939 Lawrence, J. F., Charbonneau, C. F., Ménard, C., 1991. Liquid chromatography 940 determination of domoic acid in mussels, using AOAC paralytic shellfish poison extraction 941 procedure: collaborative study. J. Assoc. Off. Anal. Chem.74, 68-72.

942

Lê, S., Josse, J., Husson, F., 2008. FactoMineR: An R Package for Multivariate Analysis. J.Stat. Soft. 25(1), 1-18.

945

Lefebvre, K.A., Frame, E.R., Kendrick, P.S., 2012. Domoic acid and fish behaviour: A review. Harmful Algae 13, 126-130. 
949

950

951

952

953

954

955

956

957

958

959

960

961

962

963

964

965

966

967

968

969

970

971

972

973

Lefebvre, K.A., Silver, M.W., Coale, S.L., Tjeerdema, R.S., 2002a. Domoic acid in planktivorous fish in relation to toxic Pseudo-nitzschia cell densities. Mar. Biol. 140, 625631.

Lefebvre, K.A., Bargu, S., Kieckhefer, T., Silver, M.W., 2002b. From sand dabs to blue whales: the pervasiveness of domoic acid. Toxicon 40, 971-977.

Le Pape, O., Menesguen, A., 1997. Hydrodynamic prevention of eutrophication in the Bay of Brest (France), a modelling approach. J. Mar. Syst.12(1), 171-186.

Legendre, P., Legendre, L., 1998. Numerical ecology. Second English Edition. Elsevier Science BV, Amsterdam, 853 pp.

Lelong, A., Hégaret, H., Soudant, P., Bates, S., 2012. Pseudo-nitzschia (Bacillariophyceae) species, domoic acid and amnesic shellfish poisoning: revisiting previous paradigms. Phycologia 51(2), 168-216.

Lorenzen, C. J., 1967. Determination of chlorophyll and pheopigments: spectrophotometric equations. Limnol. Oceanogr. 12(2), 343-346.

Lund-Hansen, L.C., Vang, T., 2004. An inflow and intrusion event in the Little Belt at the North SeaeBaltic Sea transition and a related sub-surface bloom of Pseudo-nitzschia pseudodelicatissima. Estuar. Coast. Shelf S. 59, 265-276.

Lund-Hansen, L. C., Pejrup, M., Floderus, S., 2004. Pelagic and seabed fluxes of particulate 
974

975

976

977

978

979

980

981

982

983

984

985

986

987

988

989

990

991

992

993

994

995

996

997

matter and carbon, and $\mathrm{C}$ : $\mathrm{N}$ ratios resolved by sediment traps during a spring bloom, southwest Kattegat. J. Sea Res.52(2), 87-98.

Macintyre, H. I., Stutes A. I., Smith, W. I., Dorsey, C.P., Abraham, A.,Dickey, R.W., 2011. Environmental correlates of community composition and toxicity during a bloom of Pseudonitzschia spp. in the northern Gulf of Mexico.J. Plankton Res. 93(2), 273-295.

Mercado, J. M., Ramírez, T., Cortés, D., Sebastián, M., Vargas-Yáñez, M., 2005. Seasonal and inter-annual variability of the phytoplankton communities in an upwelling area of the Alborán Sea (SW Mediterranean Sea). Sci. Mar.69(4), 451-465.

Nézan, E., Antoine, E., Fiant, L., Amzil, Z., Billard, C., 2006. Identification of Pseudonitzschiaaustralis and P. multiseries in the Bay of Seine. Was there a relation to presence of domoic acid in king scallops in autumn 2004? Harmful Algae News 31, 1-3.

Nézan, E., Chomérat, N., Bilien, G., Boulben, S., Duval, A., Ryckaert, M., 2010. Pseudonitzschia australis on French Atlantic coast-an unusual toxic bloom. Harmful Algae News 41, $1-2$.

Parsons, M. L., Dortch, Q., Fryxell, G. A., 1998. A multi-year study of the presence of potential domoic acid-producing Pseudo-nitzschia species in the coastal and estuarine waters of Louisiana, USA. Harmful Algae. Xunta de Galicia and Intergovernmental Oceanographic Commission of United Nations Educational, Scientific and Cultural Organization, Paris, France, 184-187.

998 
999 Parsons, M.L., Dortch, Q., 2002. Sedimentological evidence of an increase in Pseudo-

1000

1001

1002

1003

1004

1005

1006

1007

1008

1009

1010

1011

1012

1013

1014

1015

1016

1017

1018

1019

1020

1021

1022

1023

nitzschia (Bacillariophyceae) abundance in response to coastal eutrophication. Limnol. Oceanogr. 47(2), 551-558.

Parsons, M.L., Dortch, Q., Doucette, G.J., 2013. An assessment of Pseudo-nitzschia population dynamics and domoic acid production in coastal Louisiana, Harmful Algae 30, 6577.

Planque, B., Lazure, P., Jégou, A.M., 2004. Detecting hydrological landscapes over the Bay of Biscay continental shelf in spring. Clim. Res. 28, 41-52.

Puillat, I., Lazure P., Jégou, A-M., Lampert, L., Miller, P.I., 2004. Hydrographical variability on the French continental shelf in the Bay of Biscay, during the 1990s.Cont. Shelf Res., 25: 1143-1163.

Puillat, I., Lazure, P., Jégou, A-M., Lampert, L., Miller, P.I., 2006. Mesoscale hydrological variability induced by northwesterly wind on the French continental shelf of the Bay of Biscay. Sci. Mar.,70(1), 15-26.

R Core Team, 2013. R: A Language and Environment for Statistical Computing. Vienna, Austria: R Foundation for Statistical Computing. http://www.R-project.org/

Romero, E., Garnier, J., Lassaletta, L., Billen, G., Le Gendre, R., Riou, P., Cugier, P., 2013. Large-scale patterns of river inputs in southwestern Europe: seasonal and interannual variations and potential eutrophication effects at the coastal zone. Biogeochemistry 113, 481- 
Sakamaki, T., Nishimura, O., Sudo, R., 2006. Tidal time-scale variation in nutrient flux across the sediment-water interface of an estuarine tidal flat. Est. Coast. Shelf Sci. 67, 653-663.

Saulquin, B., Gohin, F., Garello, R., 2010. Regional objective analysis for merging highresolution MERIS, MODIS/Aqua, and SeaWiFS chlorophyll- $a$ data from 1998 to 2008 on the European Atlantic Shelf. IEEE Transactions on Geoscience and Remote Sensing, 1-12.

Schnetzer, A., Miller, P. E., Schaffner, R. A., Stauffer, B. A., Jones, B. H., Weisberg, S. B., DiGiacomo, P.M., Berelson, W.M., Caron, D. A., 2007. Blooms ofPseudo-nitzschiaand domoic acid in the San Pedro Channel and Los Angeles harbor areas of the Southern California Bight, 2003-2004. Harmful Algae6(3), 372-387.

Schnetzer, A., Jones, B. H., Schaffner, R. A., Cetinic, I., Fitzpatrick, E., Miller, P. E., Seubert, E.L., Caron, D. A., 2013. Coastal upwelling linked to toxic Pseudo-nitzschia australis blooms in Los Angeles coastal waters, 2005-2007. J. Plankton Res. 35(5), 1080-1092.

Scholin, C.A., Gulland, F., Doucette, G.J., Benson, S., Busman, M., Chavez, F., Cordaro, J., DeLong, R., De Vogelaere, A., Harvey, J., Haulean, M., Lefebvre, K., Lipscomb, T., Loscufoff, S., Lowenstine, L.J., Marin, III R., Miller, P.E., McLellan, W.A., Moeller, P.D.R., Powell, C.L., Rowles, T., Silvagni, P., Silver, M., Spraker, T., Trainer, V., Van Dolah, F.M., 2000. Mortality of sea lions along the central California coast linked to a toxic diatom bloom. Nature 403, 80-84. 
1049

1050

1051

1052

1053

1054

1055

1056

1057

1058

1059

1060

1061

1062

1063

1064

1065

1066

1067

1068

1069

1070

1071

1072

1073

Sekula-Wood, E., Benitez-Nelson,C., Morton, S., Anderson, C., Burrell, C., Thunell, R., 2011.

Pseudo-nitzschia and domoic acid fluxes in Santa Barbara Basin (CA) from 1993 to 2008.

Harmful Algae 10, 567-575.

Sekula-Wood, E., Schnetzer, A., Benitez-Nelson, C.R., Anderson, C., Berelson, W.M., Brzezinski, M.A., Burns, J.M., Caron, D.A., Cetinic, I., Ferry, J.L., Filtzpatrick, E., Jones, B.H., Miller, P.E., Morton, S.L., Schaffner, R.A., Siegel, D.A., Thunell, R., 2009. Rapid downward transport of the neurotoxin domoic acid in coastal waters. Nat.Geosci. 2, 272-275.

Shumway, S.E., Allen, S.M., Dee Boersma, P., 2003. Marine birds and harmful algal blooms: sporadic victims or under-reported events? Harmful Algae 2, 1-17.

Smith, J.C., Worms, J., Bird, C.J., Quilliam, M.A., Pocklington, R., Angus, R., Hanic, L., 1990. Toxic blooms of the domoic acid containing diatom Nitzschia pungens inn the Cardigan River, Prince Edward Island, in 1998. In: Granéli, B., Sundtrom, L., Edler, L., Anderson, D.M. (Eds.) Toxic marine phytoplankton. Elsevier, New York, pp. 227-232.

Spatharis, S., Tsirtsis, G., Danielidis, D. B., Chi, T. D., Mouillot, D., 2007. Effects of pulsed nutrient inputs on phytoplankton assemblage structure and blooms in an enclosed coastal area. Estuar. Coast. Shelf S., 73(3), 807-815.

Thorel, M., Fauchot, J., Morelle, J., Raimbault, V., Le Roy, B., Miossec, C., Claquin, P., 2014. Interactive effects of irradiance and temperature on growth and domoic acid production of the toxic diatom Pseudo-nitzschia australis(Bacillariophyceae). Harmful Algae, 39, 232241. 
1075 Trainer, V. L., Adams, N. G., Bill, B. D., Stehr, C. M., Wekell, J. C., Moeller, P., Busman, M., 1076 Woodruff, D., 2000. Domoic acid production near California coastal upwelling zones, June 1077 1998. Limnol. Oceanogr. 45(8), 1818-1833.

1078

1079 Trainer, V. L., Cochlan, W. P., Erickson, A., Bill, B. D., Cox, F. H., Borchert, J. A., Lefebvre,

K. A., 2007. Recent domoic acid closures of shellfish harvest areas in Washington State in1081 land waterways. Harmful Algae6(3), 449-459.

1082

Trainer, V.L., Bates, S.S., Lundholm, N., Thessen, A.E., Cochlan, W.P., Adams, N.G., Trick,

C.G., 2012.Pseudo-nitzschia physiological ecology, phylogeny, toxicity, monitoring and impacts on ecosystem health. Harmful Algae 14, 271-300.

1086

1087

Utermöhl, H., 1958. Z ur vervollkommnung der quantitativen phytoplankton-methodik.Mitt. int. Ver. theor. angew. Limnol.9, 1-38.

Van de Waal, D. B., Smith, V. H., Declerck, S. A., Stam, E., \& Elser, J. J. (2014). Stoichiometric regulation of phytoplankton toxins. Ecology letters, 17(6), 736-742.

1092

Vale, P., Sampayo, M.A., 2001. Domoic acid in Portuguese shellfish and fish. Toxicon 39, 893-904.

Wright, J.L.C., Boyd, R.K., de Freitas, A.S.W., Falk, M., Foxall, R.A., Foxall, R.A., Odense, P., Pathak, V., Quilliam, M.A., Ragan, M.A., Sim, P.G., Thibault, P., Walter, J.A., Gilgan, M., Richard, D.J.A., Dewar, D., 1989. Identification of domoic acid, a neuroexcitatory amino 
1099 acid, in toxic mussels from eastern Prince Edward Island. Can. J. Chem. 67, 481-490.

1100

1101 


\section{Figures captions}

2

3 Figure 1. Location of the six studied bays scattered along the French coast and annual

4

Figure 2: Box plots of the winter variation of nutrients $\mathrm{PO}_{4}, \mathrm{SiOH}$ and $\mathrm{DIN}\left(\mu \mathrm{mol} 1^{-1}\right)$, and their ratio.Horizontal lines symbolize the median value for each bay, boxes represent lower and upper quartiles, and dots are outliers.

Figure 3: A) Monthly median of chlorophyll $a$ concentrations $\left(\mu \mathrm{g}^{-1}\right)$, salinity, temperature $\left({ }^{\circ} \mathrm{C}\right)$, turbidity (NTU) and Photosynthetic Active radiation (PAR; $10^{3} \mathrm{w} \mathrm{m}^{-2}$ ) calculated over the 1998 to 2012 period in each bay. B) Box plots of the annual variation of chlorophyll $a$ concentrations $\left(\mu \mathrm{g} \mathrm{l}^{-1}\right)$, salinity, temperature $\left({ }^{\circ} \mathrm{C}\right)$, turbidity (NTU) and Photosynthetic Active radiation (PAR; $10^{3} \mathrm{~W} \mathrm{~m}^{-2}$ ) calculated over the 1998 to 2012 period in each bay. For B) horizontal lines symbolize the median value for each bay, boxes represent lower and upper quartiles, and dots are outliers.

Figure 4 : Seasonal patterns of Pseudo-nitzschia spp. blooms for each of the 6 study sites. (A) Median abundance and (B) lower (Q1) and upper (Q2) quartiles regions calculated for each site over the 1995 to 2012 period. 
Figure 5: Principal Component Analysis (PCA) conducted on phytoplankton biodiversity index and Pseudo-nitzschia spp. descriptors from the 6 studied bays. (A) Variables vector map and (B) Individuals factor map. 'PSN-Rank': rank of Pseudo-nitzschia spp. within the phytoplankton community; 'S': phytoplankton richness; 'J': Berger-Parker evenness; 'TOT': total phytoplankton abundances; '\%Diat': the proportion of diatoms versus diatoms plus dinoflagellates; 'PSN': Pseudo-nitzschia spp. abundances; '\%PSN': relative abundance of Pseudo-nitzschia spp. within the phytoplankton community.

Figure 6: Pseudo-nitzschia spp. abundances $(\log ($ Abund. + 1) ) over the 1995 to 2012 period at the six study sites; (A) Seine bay, (B) Saint Brieuc bay, (C) Brest bay, (D) Concarneau bay, (E) Quiberon bay and (F) Pertuis Breton. For the Seine bay (A), data were not available before 1997.

Figure 7: Environmental niche of Pseudo-nitzschia. SALI: salinity; TEMP: temperature $\left({ }^{\circ} \mathrm{C}\right)$; TURB.: turbidity (NTU); PO4 : phosphates $\left(\mu \mathrm{mol} 1^{-1}\right)$; SIOH: silicate $\left(\mu \mathrm{mol}{ }^{-1}\right)$; DIN : dissolved inorganic nitrogen $\left(\mu \mathrm{mol} 1^{-1}\right) ; \mathrm{N} / \mathrm{P}: \mathrm{DIN} / \mathrm{PO} 4$ ratio ; Si/N : SiOH/DIN ratio ; Si/P : SiOH/PO4 ratio ; PAR: Photosynthetic Active Radiation $\left(\mathrm{W} \mathrm{m}^{-2}\right)$. Gradient from white to black shows increasing abundances of Pseudo-nitzschia, as calculated from the weighed Kernel density. Contours mark respectively $25 \%, 50 \%$ and $75 \%$ of highest densities of Pseudo-nitzschia.

Figure 8: A) Scallops Toxicity Index (STI; $\mu \mathrm{g} \mathrm{DA} \mathrm{g} \mathrm{g}^{-1} \mathrm{ww} \mathrm{y}^{-1}$ ) and (B) annual maximum Pseudo-nitzschia spp. abundances $\left(10^{6}\right.$ cells $\left.1^{-1}\right)$ over the 2003 to 2012 period at the 6 study sites. 


\section{Figure}

Click here to download high resolution image

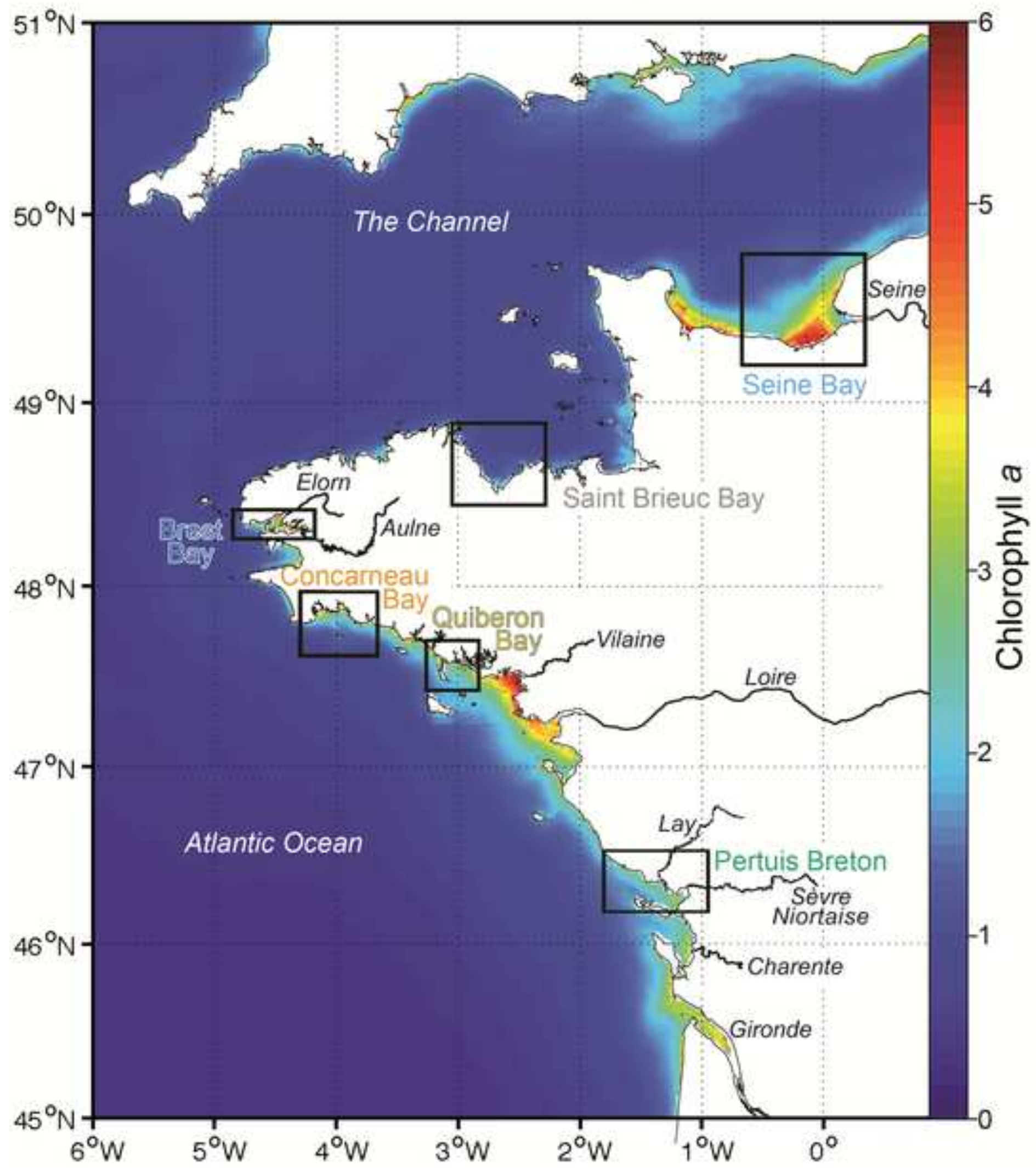



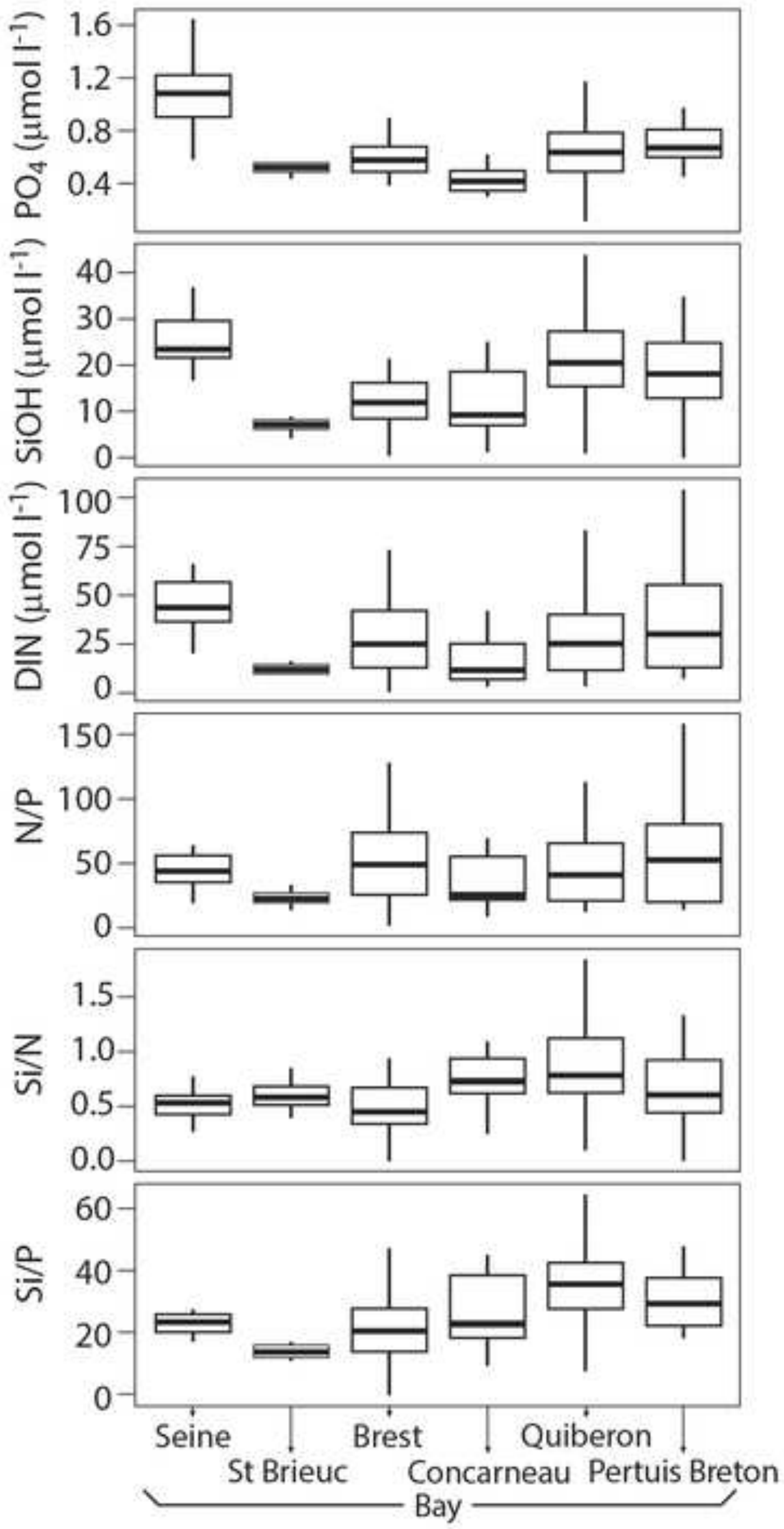


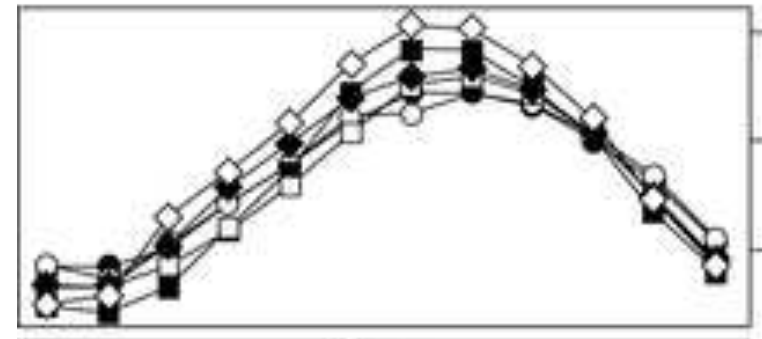

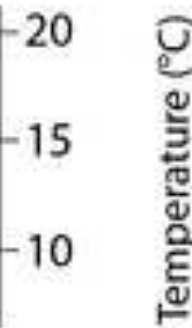
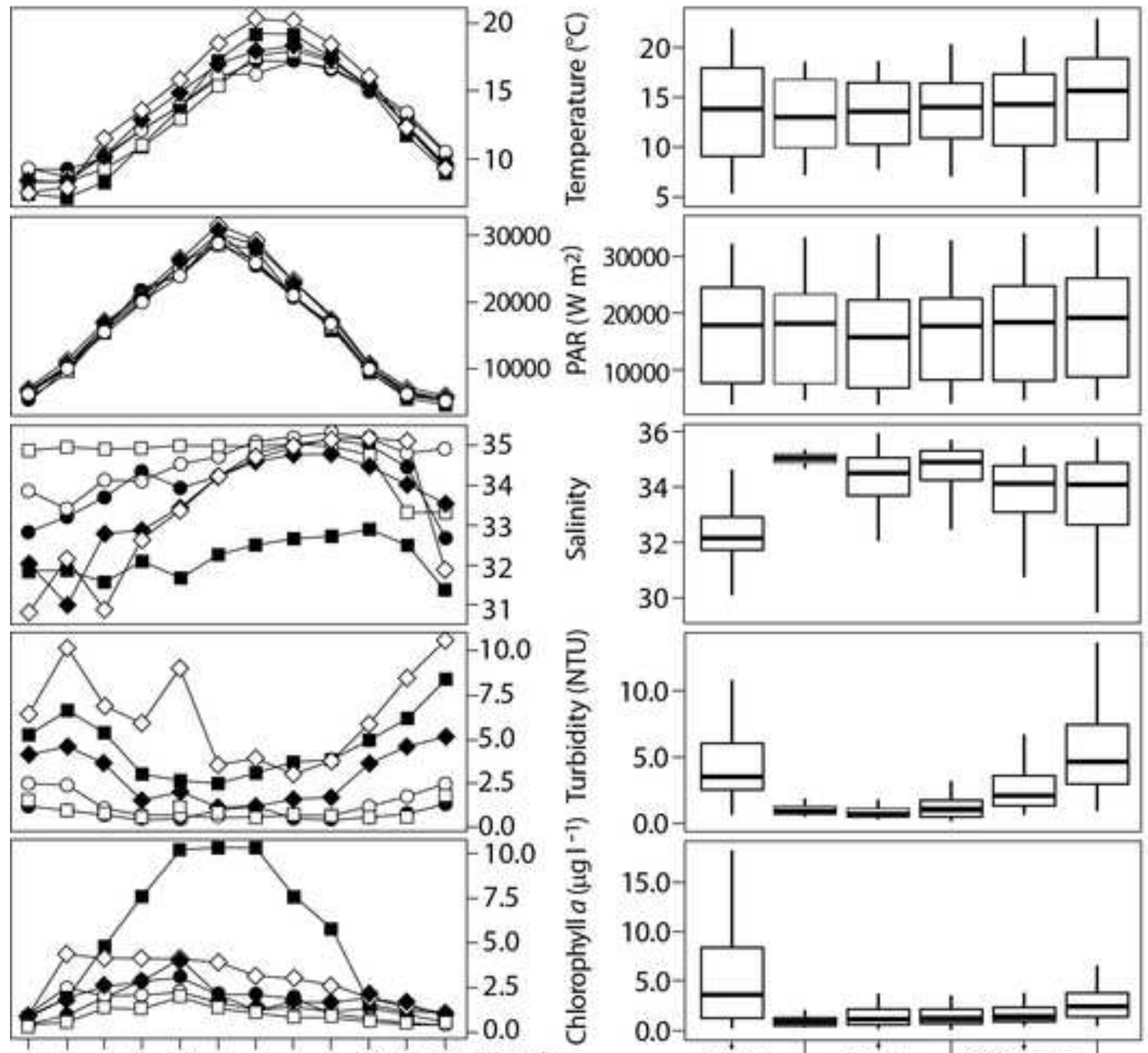

-0.0
-10.0
-7.5
-5.0
-2.5
-0.0

J F M A M J A S O N D $\rightarrow$ Months

- Seine Bay

$-\square-$ St Brieuc Bay

- - Concarneau Bay

$\rightarrow$ Brest Bay

- Quiberon Bay
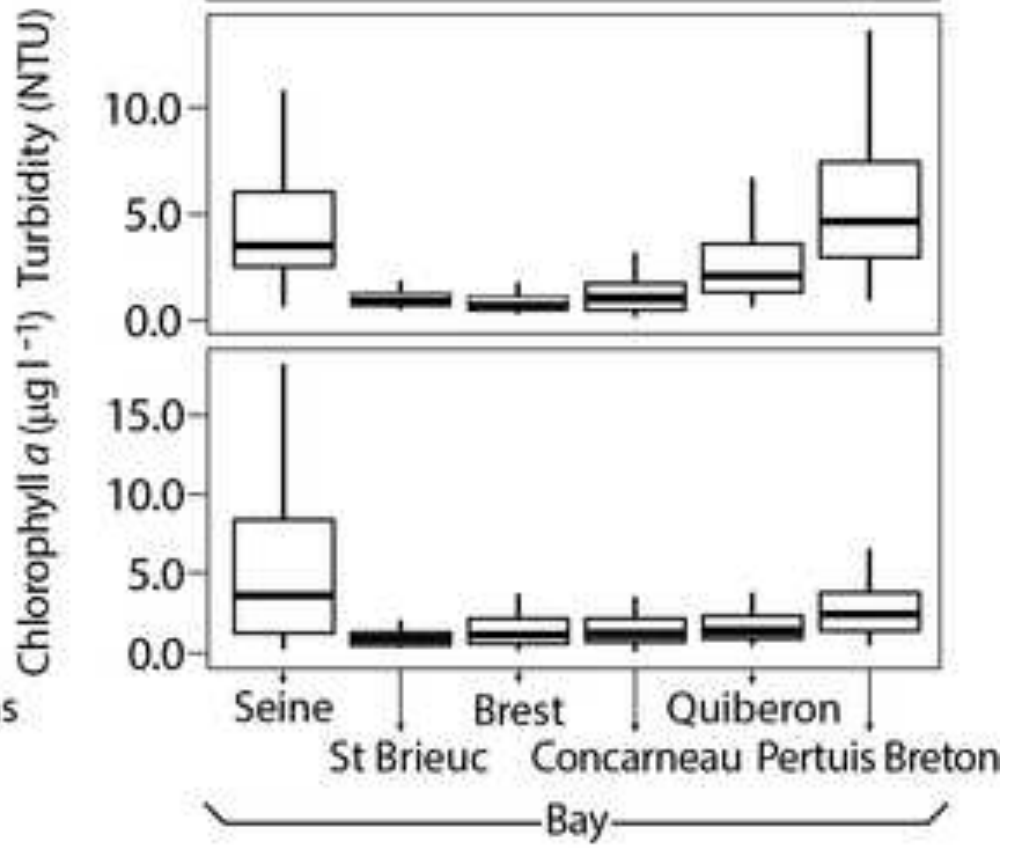


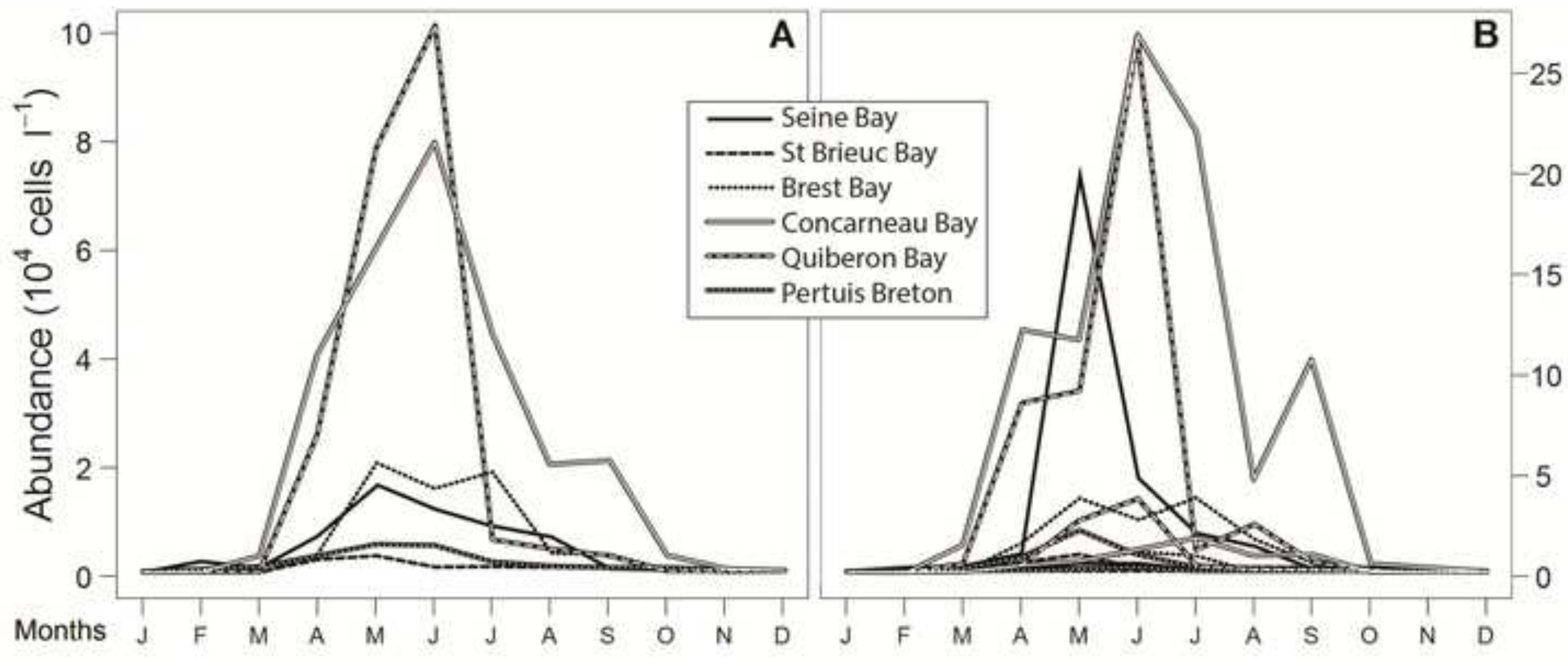


$\operatorname{Dim} 2$ (19.92\%)

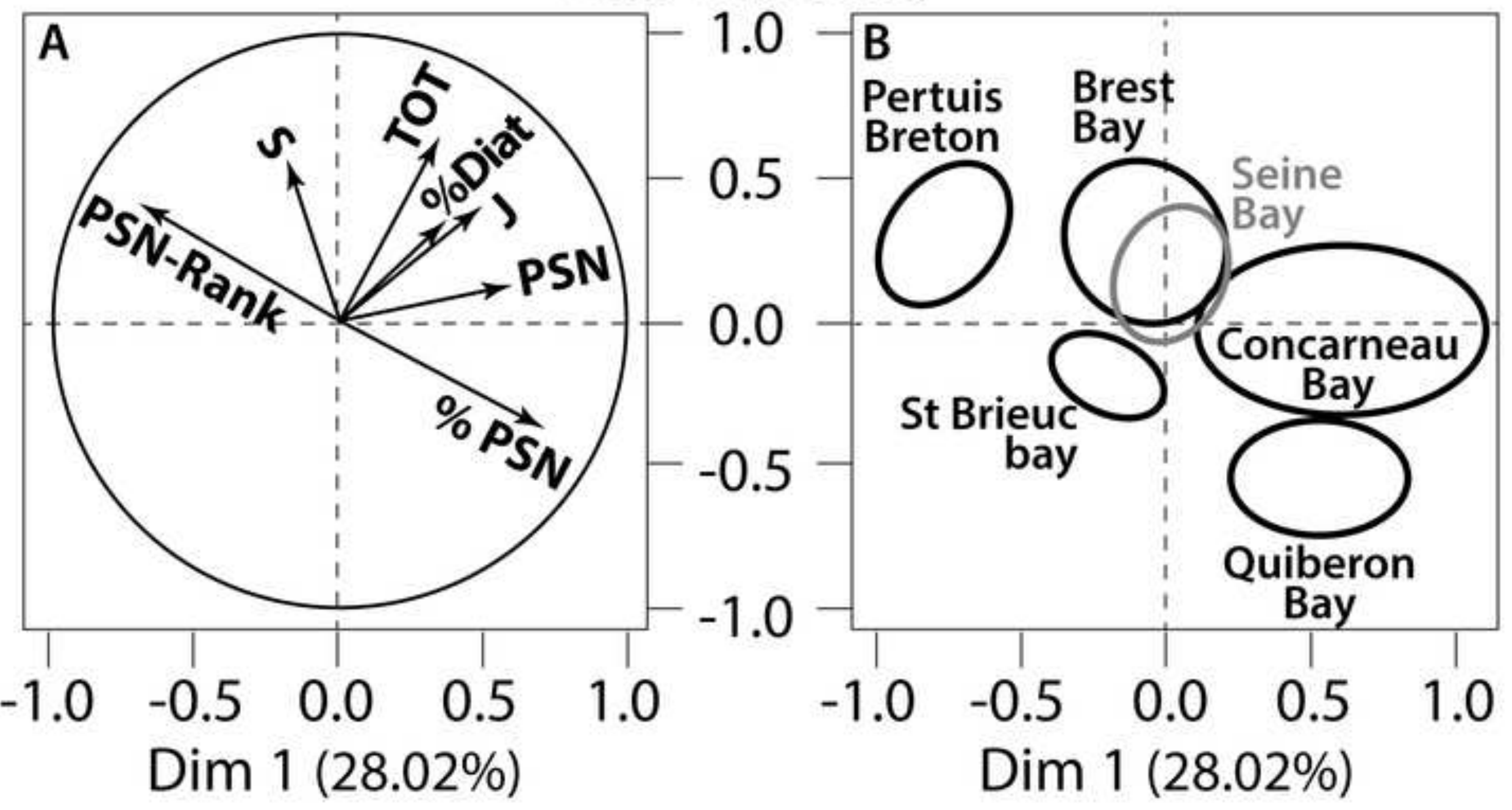



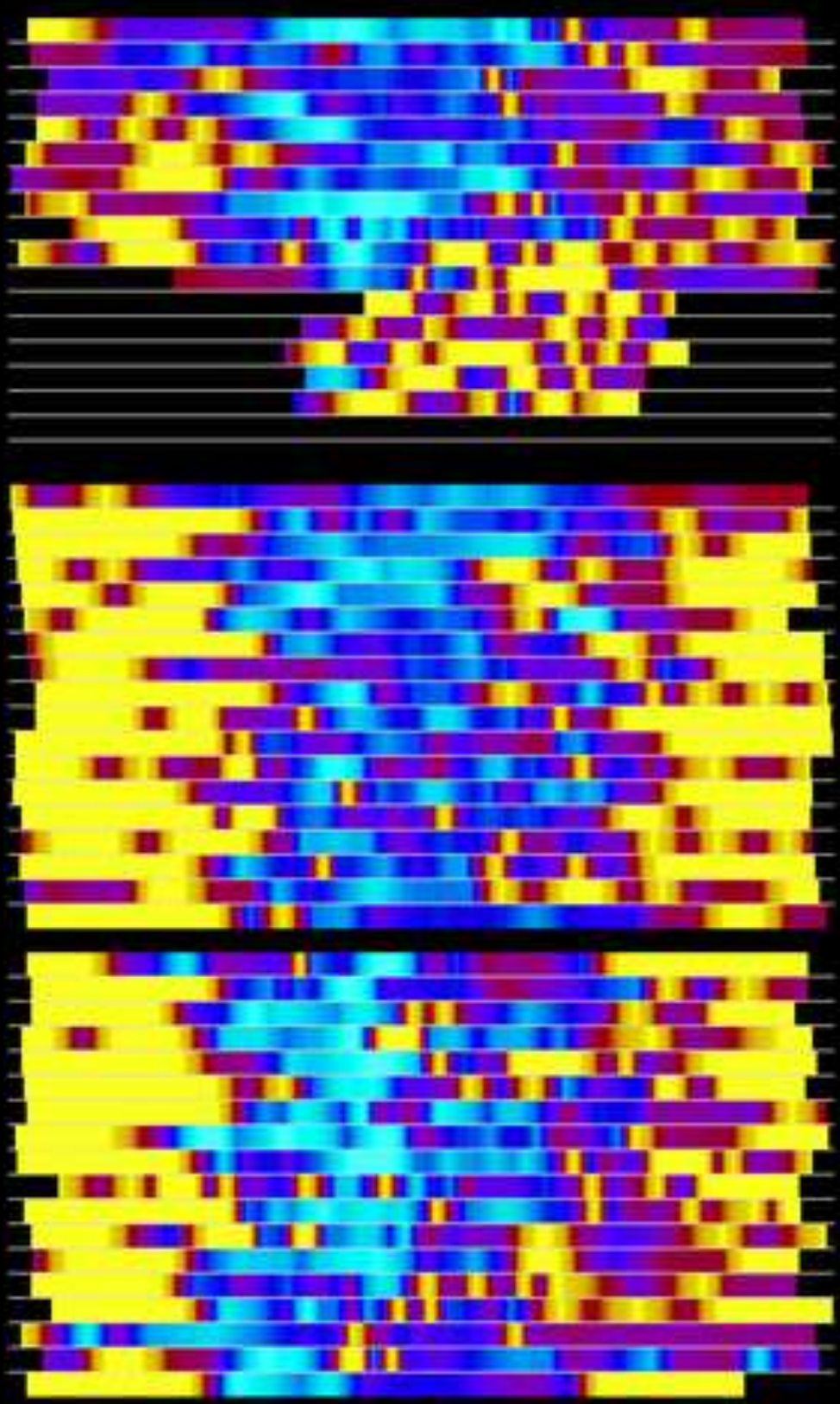

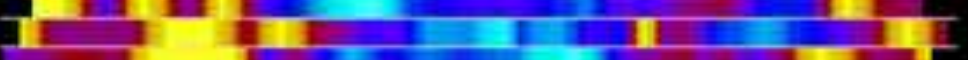
In

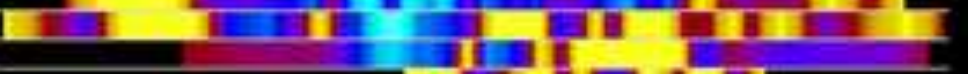
ב

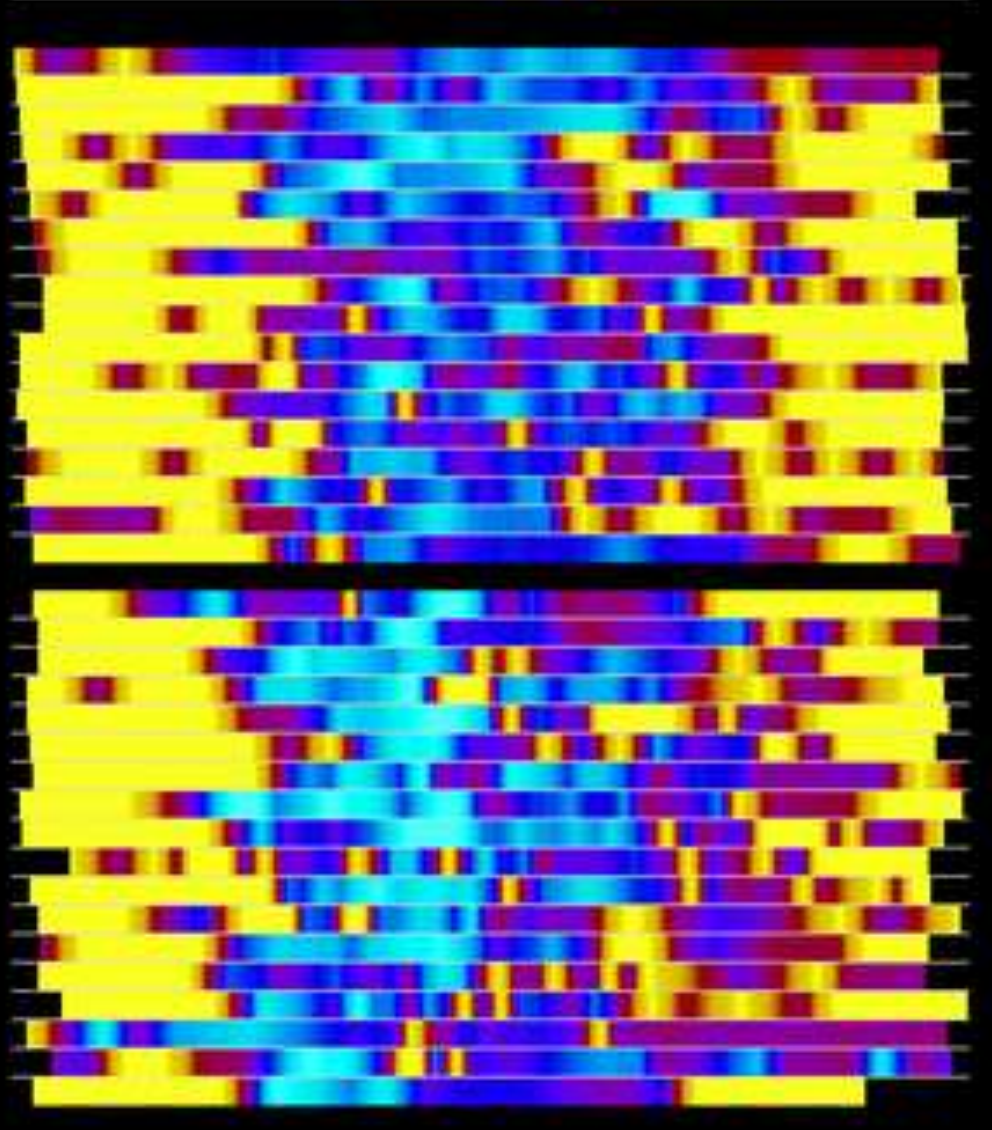

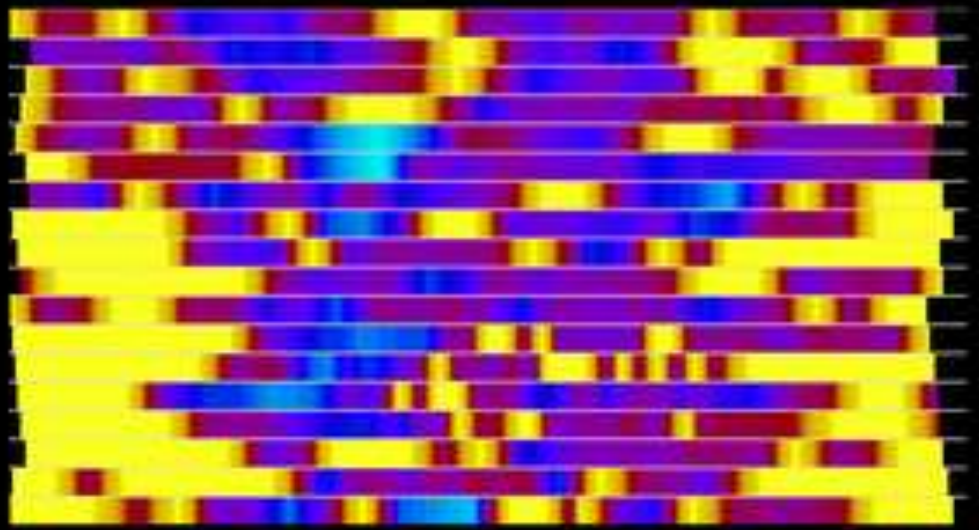

I

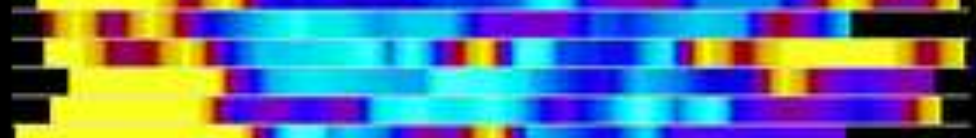

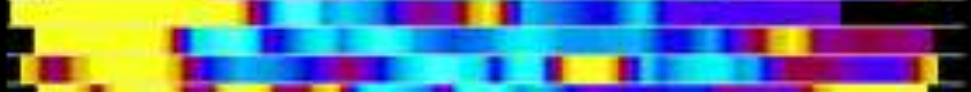

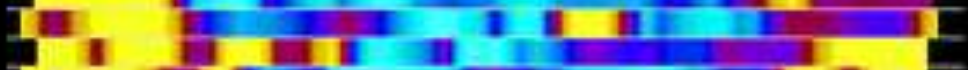
I

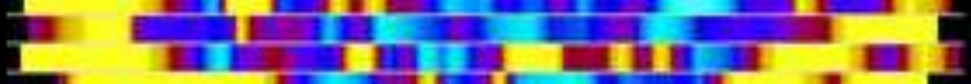

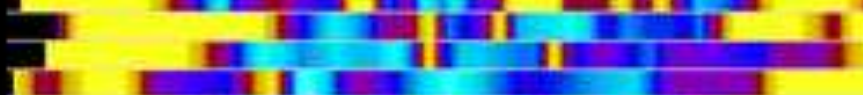

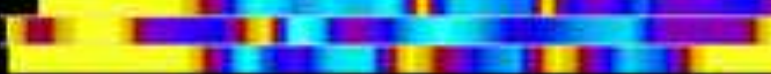

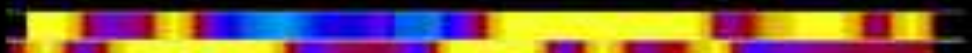

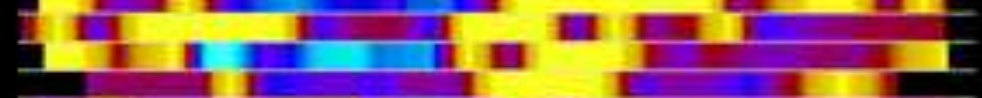
可国

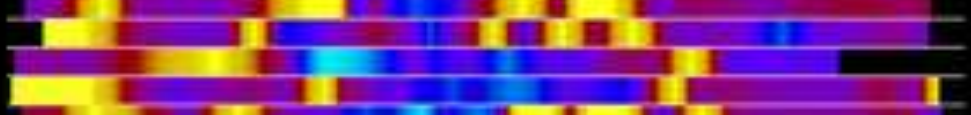

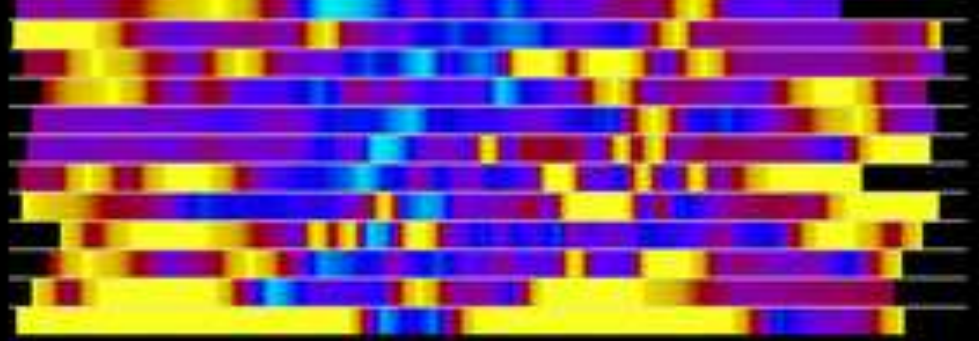

$$
\text { (20) }
$$




\section{Figure}

Click here to download high resolution image

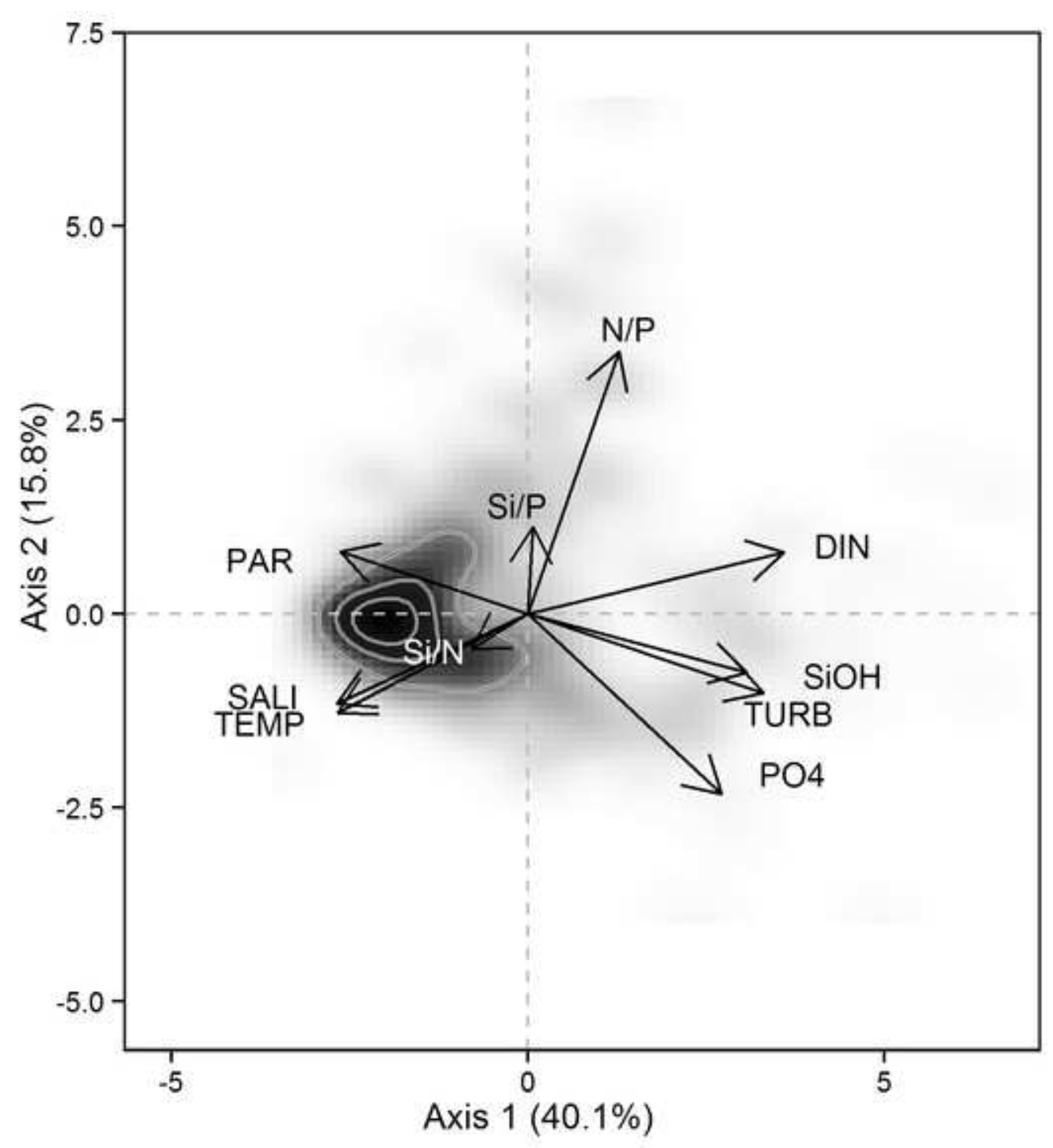




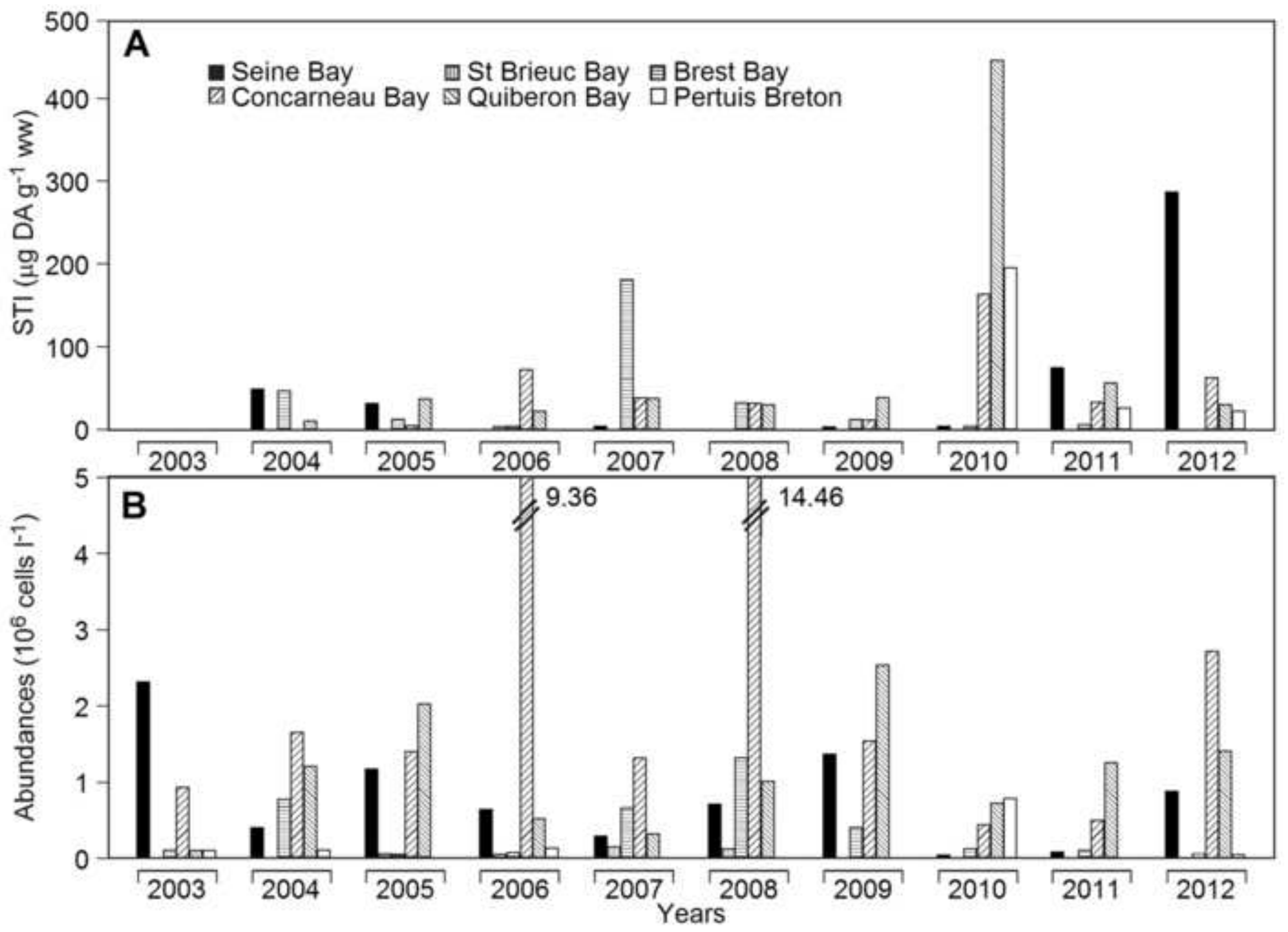


1 Two decades of Pseudo-nitzschia spp. blooms and king scallop (Pecten

2 maximus) contamination by domoic acid along the French Atlantic and

3 English Channel coasts: seasonal dynamics, spatial heterogeneity and

4 interannual variability

5

6 Bérengère Husson $^{\mathrm{a}}$, Tania Hernández-Fariñas ${ }^{\mathrm{b}}$, Romain Le Gendre ${ }^{\mathrm{c}}$, MathildeSchapira ${ }^{\mathrm{d}}$, $7 \quad$ Annie Chapelle e, $^{*}$

8

9 Tables

10

Table 1

12 Geographic coordinates and lowest astronomical tide (LAT) of the 6 sampling stations in each

13 studied bays

\begin{tabular}{lllll}
\hline & Sampling station & Latitude & Longitude & LAT $^{*}(\mathrm{~m})$ \\
\hline Seine bay & Cabourg & $49^{\circ} 18.50^{\prime} \mathrm{N}$ & $0^{\circ} 07.54^{\prime} \mathrm{W}$ & 5.0 \\
St Brieuc bay & Loguivy & $48^{\circ} 49.72^{\prime} \mathrm{N}$ & $3^{\circ} 02.51^{\prime} \mathrm{W}$ & 3.5 \\
Brest bay & Lanveoc & $48^{\circ} 18.56^{\prime} \mathrm{N}$ & $4^{\circ} 26.91^{\prime} \mathrm{W}$ & 18.5 \\
Concarneau bay & Concarneau & $47^{\circ} 50.00^{\prime} \mathrm{N}$ & $3^{\circ} 56.99^{\prime} \mathrm{W}$ & 20.0 \\
Quiberon bay & Men erRoue & $47^{\circ} 32.08^{\prime} \mathrm{N}$ & $3^{\circ} 05.62^{\prime} \mathrm{W}$ & 9.5 \\
Pertuis Breton & L'éperon & $46^{\circ} 16.38^{\prime} \mathrm{N}$ & $1^{\circ} 14.03^{\prime} \mathrm{W}$ & 1.0 \\
\hline
\end{tabular}

* LowestAstronomical Tide 


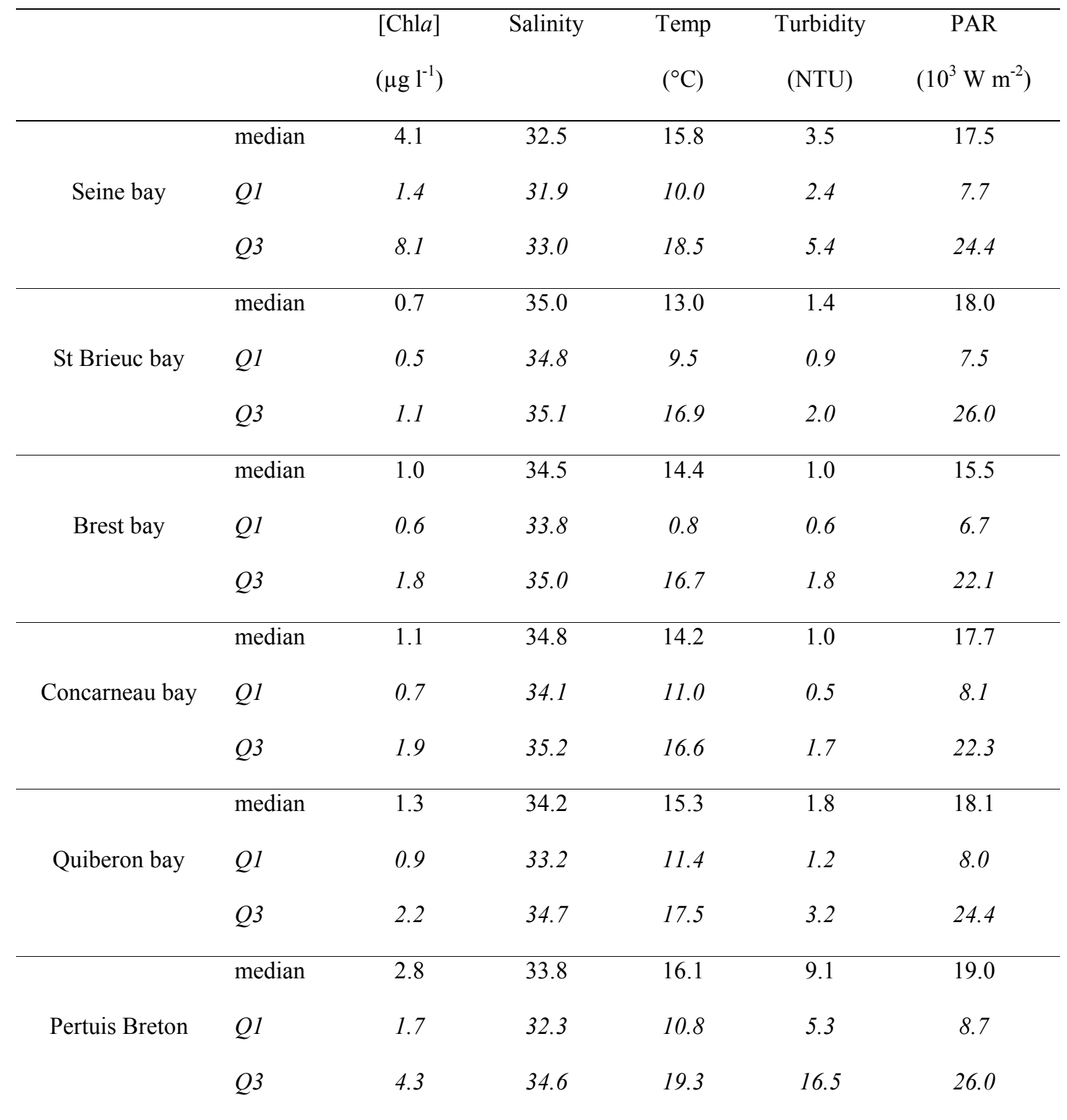

Table 2.

Environmental characteristics of the 6 studied bays. Median values and lower (Q1) and upper quartile (Q3) calculated over the 1995 to 2012 period. For the Seine bay, data were not available before 1997. [Chla]: chlorophyll $a$ concentrations $\left(\mu \mathrm{g} 1^{-1}\right)$; T: temperature $\left({ }^{\circ} \mathrm{C}\right)$; Turb.: turbidity (NTU); PAR: Photosynthetic Active Radiation $\left(10^{3} \mathrm{~W} \mathrm{~m}^{-2}\right)$. Chla concentration, salinity, temperature and turbidity were measured in the field from sub-surface. Photosynthetic Active Radiation (PAR) were obtained with the ARPEGE model (Météo France) and the daily PAR was cumulated over the five days preceding samplings. 
26 Table 3

27 First and third quantile values for environmental parameters corresponding to the 5\% most

28 abundant Pseudo-nitzschia data in Figure 7. SALI: salinity; TEMP: temperature $\left({ }^{\circ} \mathrm{C}\right)$; TURB:

29 turbidity (NTU); PO4 : phosphate $\left(\mu \mathrm{mol} 1^{-1}\right)$; SIOH: silicate $\left(\mu \mathrm{mol} 1^{-1}\right)$; DIN : dissolved 30 inorganic nitrogen $\left(\mu \mathrm{mol} \mathrm{l}^{-1}\right)$; N/P ratio ; Si/N ratio ; Si/P ratio ;PAR: Photosynthetic Active 31 Radiation $\left(\mathrm{W} \mathrm{m}^{-2}\right)$.

\begin{tabular}{ccr}
\hline & Minimum & Maxim 3if \\
\hline SALI & 34.02 & \multicolumn{1}{c}{35.2} \\
TEMP & 15.91 & $17.95^{33}$ \\
TURB & 0.44 & $1.35^{34} 35$ \\
PO4 & 0.08 & 0.1436 \\
SIOH & 1.175 & 4.6237 \\
DIN & 0.34 & 1.1138 \\
N/P & 2.63 & 1139 \\
Si/N & 1.84 & 5.7140 \\
Si $/$ P & 11 & 43.0441 \\
PAR & 21791 & 282242 \\
\hline & & 43
\end{tabular}

44 